\title{
ANSI/ASHRAE/IES \\ Standard 90.1-2010 Final Determination Quantitative Analysis
}

\author{
M Halverson M Rosenberg \\ B Liu
}

October 2011

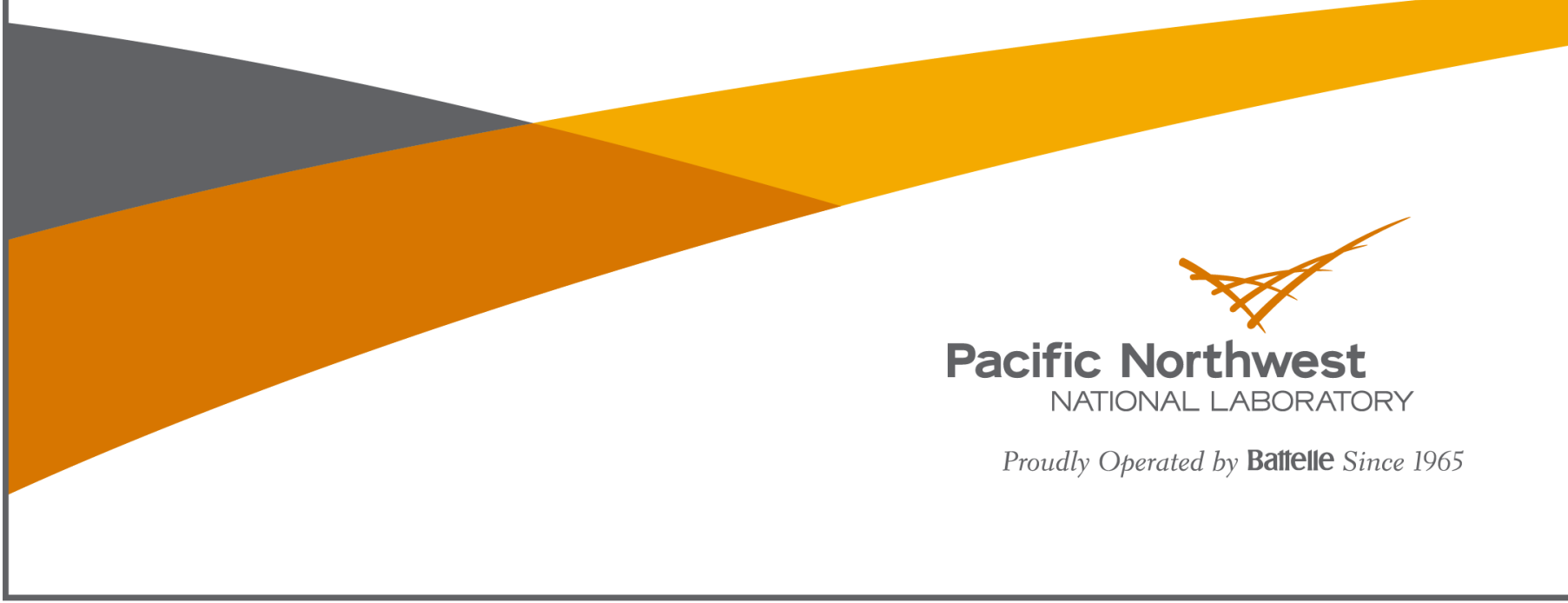




\title{
DISCLAIMER
}

This report was prepared as an account of work sponsored by an agency of the United States Government. Neither the United States Government nor any agency thereof, nor Battelle Memorial Institute, nor any of their employees, makes any warranty, express or implied, or assumes any legal liability or responsibility for the accuracy, completeness, or usefulness of any information, apparatus, product, or process disclosed, or represents that its use would not inf ringe privately owned rights. Reference herein to any specific commercial product, process, or service by trade name, trademark, manufacturer, or otherwise does not necessarily constitute or imply its endorsement, recommendation, or favoring by the United States Government or any agency thereof, or Battelle Memorial Institute. The views and opinions of authors expressed herein do not necessarily state or reflect those of the United States Government or any agency thereof.

\author{
PACIFIC NORTHWEST NATIONAL LABORATORY \\ operated by \\ BATTELLE \\ for the \\ UNITED STATES DEPARTMENT OF ENERGY \\ under Contract DE-AC05-76RL01830
}

Printed in the United States of America
Available to DOE and DOE contractors from the
Office of Scientific and Technical Information
P.O. Box 62, Oak Ridge, TN 37831-0062;
ph: (865) 576-8401
fax: $(865) 576-5728$
email: reports@adonis.osti.gov

Available to the public from the National Technical Information Service

5301 Shawnee Rd., Alexandria, VA 22312

ph: (800) 553-NTIS (6847)

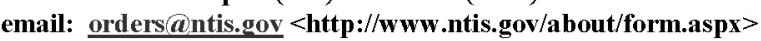

Online ordering: http://www.ntis.gov

This document was printed on recycled paper. 


\title{
ANSI/ASHRAE/IES Standard 90.1- 2010 Final Determination Quantitative Analysis
}

\author{
M Halverson \\ M Rosenberg \\ B Liu
}

October 2011

Prepared for

the U.S. Department of Energy

under Contract DE-AC05-76RL01830

Pacific Northwest National Laboratory

Richland, Washington 99352 



\section{Summary}

The U.S. Department of Energy (DOE) conducted a final quantitative analysis to assess whether buildings constructed according to the requirements of the American National Standards Institute (ANSI)/American Society of Heating, Refrigerating and Air-Conditioning Engineers (ASHRAE)/Illuminating Engineering Society (IES) Standard 90.1-2010 (ASHRAE Standard 90.1-2010, Standard 90.1-2010, or 2010 edition) would result in energy savings compared with buildings constructed to ANSI/ASHRAE/Illuminating Engineering Society of North America ${ }^{1}$ (IESNA) Standard 90.12007(ASHRAE Standard 90.1-2007, Standard 90.1-2007, or 2007 edition). The final analysis considered each of the 109 addenda to ASHRAE Standard 90.1-2007 that were included in ASHRAE Standard 90.12010. All 109 addenda processed by ASHRAE in the creation of Standard 90.1-2010 from Standard 90.1-2007 were reviewed by DOE, and their combined impact on a suite of 16 building prototype models in 15 ASHRAE climate zones was considered. Most addenda were deemed to have little quantifiable impact on building efficiency for the purpose of DOE's final determination. However, out of the 109 addenda, 34 were preliminarily determined to have a measureable and quantifiable impact.

A suite of 240 computer energy simulations for building prototypes complying with ASHRAE 90.12007 was developed. These prototypes were then modified in accordance with these 34 addenda to create a second suite of corresponding building simulations reflecting the same buildings compliant with Standard 90.1-2010. The building simulations were conducted using the DOE EnergyPlus building simulation software. The resulting energy use from the complete suite of 480 simulation runs was then converted to energy use intensity (EUI, or energy use per unit floor area) metrics (Site EUI, Primary EUI, and energy cost intensity [ECI]) results for each simulation. For each edition of the standard, these EUIs were then aggregated to a national basis for each prototype using weighting factors based on construction floor area developed for each of the 15 U.S. climate zones using commercial construction data. When compared, the resulting weighted EUIs indicated that each of the 16 building prototypes used less energy under Standard 90.1-2010 than under Standard 90.1-2007 on a national basis when considering site energy, primary energy, or energy cost. The EUIs were also aggregated across building types to a national commercial building basis using the same weighting data. On a national basis, the final quantitative analysis estimated a floor-space-weighted national average reduction in new building energy consumption of 18.2 percent for source energy and 18.5 percent when considering site energy. An 18.2 percent savings in energy cost, based on national average commercial energy costs for electricity and natural gas, was also estimated.

\footnotetext{
${ }^{1}$ IES and IESNA are the same organization. The 2007 edition used the name "IESNA", while the 2010 edition uses the name "IES".
} 


\section{Acronyms and Abbreviations}

\begin{tabular}{|c|c|}
\hline${ }^{\circ} \mathrm{F}$ & degree(s) Fahrenheit \\
\hline AEO & Annual Energy Outlook \\
\hline ANSI & American National Standards Institute \\
\hline ARI & Air-Conditioning and Refrigeration Institute \\
\hline ASHRAE & American Society of Heating, Refrigerating and Air-Conditioning Engineers \\
\hline BECP & Building Energy Codes Program \\
\hline Btu & British thermal unit(s) \\
\hline $\mathrm{Btu} / \mathrm{h}$ & British thermal unit(s) per hour \\
\hline $\mathrm{Btu} / \mathrm{kWh}$ & British thermal unit per kilowatt-hour \\
\hline CBECS & Commercial Building Energy Consumption Survey \\
\hline $\mathrm{COP}$ & coefficient of performance \\
\hline $\mathrm{DCV}$ & demand-control(led) ventilation \\
\hline DDC & direct digital control(s) \\
\hline DOE & U.S. Department of Energy \\
\hline ECB & energy cost budget \\
\hline $\mathrm{ECI}$ & energy cost intensity \\
\hline EER & energy efficiency ratio \\
\hline EIA & Energy Information Administration \\
\hline EISA & Energy Independence and Security Act \\
\hline EPCA & Energy Policy and Conservation Act \\
\hline EUI & energy use intensity \\
\hline $\mathrm{ft}^{2}$ & square (foot)feet \\
\hline $\mathrm{ft}^{3}$ & cubic (foot)feet \\
\hline hp & horsepower \\
\hline h or hr & hour(s) \\
\hline in. & $\operatorname{inch}(\mathrm{es})$ \\
\hline HVAC & heating, ventilation, and air-conditioning \\
\hline IEER & integrated energy efficiency ratio \\
\hline IES & Illuminating Engineering Society \\
\hline IESNA & Illuminating Engineering Society of North America \\
\hline IPLV & integrated part load value \\
\hline kBtu & kilo British thermal unit(s) \\
\hline $\mathrm{kWh}$ & kilowatt hour(s) \\
\hline LPD & lighting power density \\
\hline NFRC & National Fenestration Rating Council \\
\hline PBA & principal building activity \\
\hline PNNL & Pacific Northwest National Laboratory \\
\hline SHGC & solar heat gain coefficient \\
\hline SSPC & Standing Standards Product Committee \\
\hline TMY & typical meteorological year \\
\hline
\end{tabular}


U.S.C.

VAV

VRF

W

yr
U.S. Code

variable air volume

Variable Refrigerant Flow

watt(s)

year(s) 


\section{Contents}

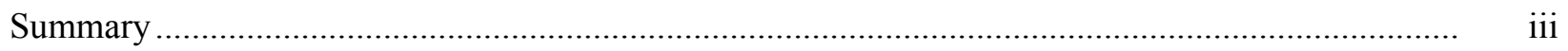

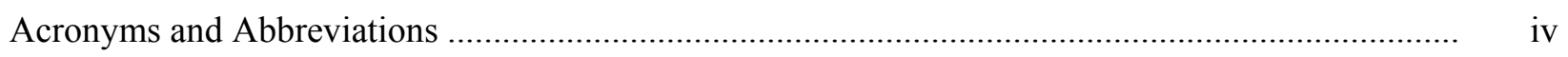

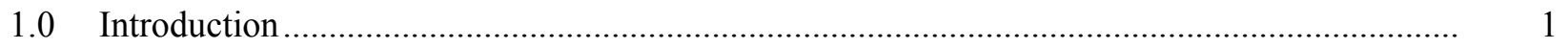

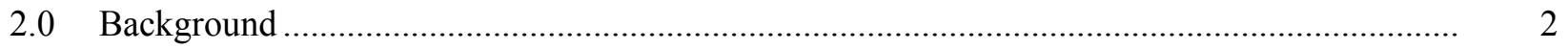

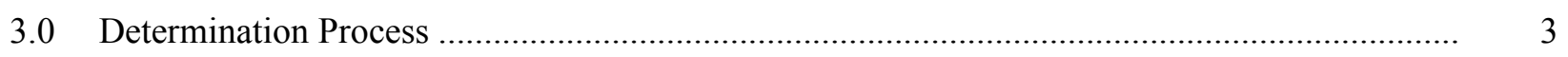

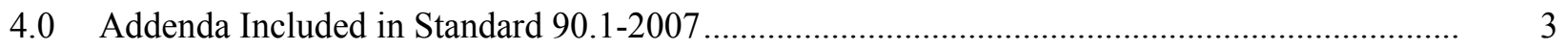

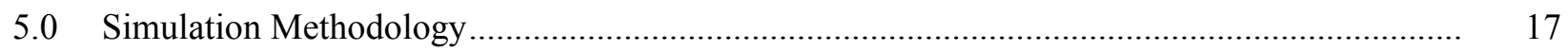

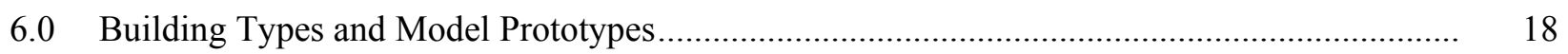

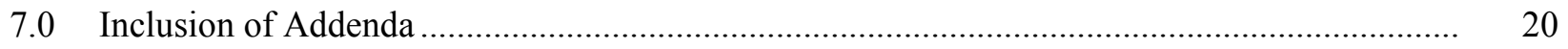

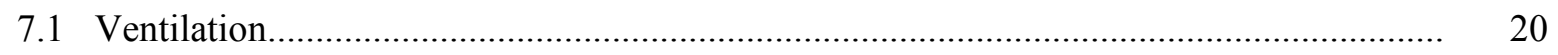

7.2 Equipment Efficiency and Mandatory Federal Efficiency Standards ............................... 21

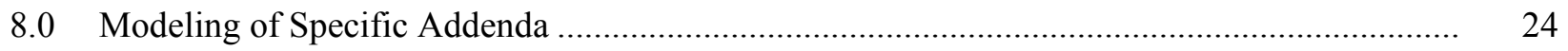

9.0 Simulation of Prototypes and Extraction of Results ........................................................... 24

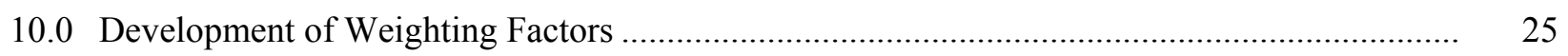

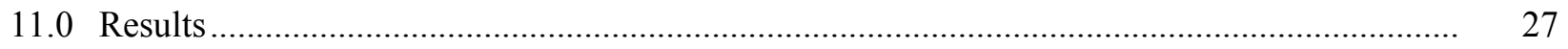

\section{Tables}

1 Addenda to ASHRAE Standard 90.1-2007, Changes Identified............................................ 5

2 ASHRAE Commercial Reference Building Models ........................................................... 19

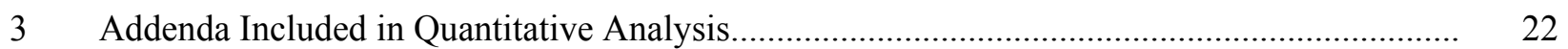

4 Relative Construction Volume Weights for 16 ASHRAE Building Prototypes by Climate

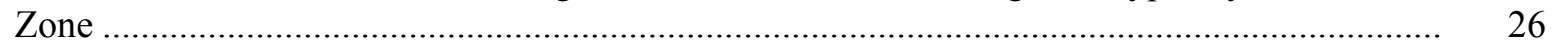

$5 \quad$ Estimated Energy Use Intensity by Building Type - 2007 Edition ....................................... 27

$6 \quad$ Estimated Energy Use Intensity by Building Type - 2010 Edition ....................................... 28

$7 \quad$ Estimated Percent Energy Savings with 2010 Edition - by Building Type .............................. 29 


\subsection{Introduction}

In support of the U.S. Department of Energy's (DOE's) determination of energy savings of American National Standards Institute (ANSI)/American Society of Heating, Refrigerating and Air-Conditioning Engineers (ASHRAE)/Illuminating Engineering Society (IES) Standard 90.1-2010 (ASHRAE Standard 90.1-2010, Standard 90.1-2010, or 2010 edition), staff from Pacific Northwest National Laboratory's (PNNL's) Building Energy Codes Program (BECP) prepared an assessment of the relative energy use for commercial buildings designed to meet building design requirements found in ASHRAE 90.1-2010 as opposed to meeting design requirements found in ANSI/ASHRAE/Illuminating Engineering Society of North America $^{1}$ (IESNA) Standard 90.1-2007(ASHRAE Standard 90.1-2007, Standard 90.1-2007, or 2007 edition).

This document provides an evaluation of the energy savings achieved by using ASHRAE Standard 90.1-2010 over its predecessor, ASHRAE Standard 90.1-2007. The evaluation was carried out using computer simulations of prototype buildings constructed to both Standard 90.1-2007 and Standard 90.12010 across a range of U.S. climates. Each building prototype used in the simulation analysis was first developed as a computer model in accordance with design and construction requirements found in Standard 90.1-2007. Changes to the building model, consistent with addenda published to Standard 90.12007 in the development of Standard 90.1-2010, were made to reflect the building as constructed under the requirements of Standard 90.1-2010. The set of Standard 90.1-2007 buildings and Standard 90.12010 buildings were simulated and energy use statistics are extracted from each building model in the form of annual energy use by fuel type. The annual energy use was then converted to energy use intensity (EUI) figures expressed in energy use per square foot. Using weighting factors by building type and geographic area developed from 5 years of recent construction data, these energy use statistics are then aggregated to national levels for each revision of the Standard 90.1, both by building prototype and weighted across building type. DOE uses these data to assess whether a positive determination can be made for ASHRAE Standard 90.1-2010.

The ensuing sections of this document describe

- characterization of the building models

- characterization of the addenda to be modeled for ASHRAE 90.1-2007

- the simulation tool used

- translation of the addenda into engineering parameters used in the computer simulations

- use of building construction weights to aggregate results from simulations across building types and locations into national results

- results of the analysis with regard to the overall EUI for buildings under both standards and the energy and energy cost savings of the standard (expressed as a percentage change in EUI).

\footnotetext{
${ }^{1}$ IES and IESNA are the same organization. The 2007 edition used the name "IESNA", while the 2010 edition uses the name "IES".
} 


\subsection{Background}

Title III of the Energy Policy and Conservation Act, as amended (EPCA), establishes requirements for the Building Energy Efficiency Standards Program (42 U.S.C. 6831 et seq.). Section 304(b), as amended, of EPCA provides that whenever the ANSI/ASHRAE/IESNA 90.1-1989 (Standard 90.1-1989 or 1989 edition), or any successor to that code, is revised, the Secretary must make a determination, not later than 12 months after such revision, whether the revised code would improve energy efficiency in commercial buildings and must publish notice of such determination in the Federal Register (42 U.S.C. 6833 (b)(2)(A)). The Secretary may determine that the revision of Standard 90.1-1989, or any successor thereof, improves the level of energy efficiency in commercial buildings. If so, then not later than 2 years after the date of the publication of such affirmative determination, each State is required to certify that it has reviewed and updated the provisions of its commercial building code regarding energy efficiency with respect to the revised or successor code (42 U.S.C. 6833(b)(2)(B)(i)). The State must include in its certification a demonstration that the provisions of its commercial building code, regarding energy efficiency, meet or exceed the revised standard (42 U.S.C. 6833(b)(2)(B)(i)).

If the Secretary makes a determination that the revised standard will not improve energy efficiency in commercial buildings, State commercial codes shall meet or exceed the last revised standard for which the Secretary has made a positive determination (42 U.S.C. 6833(b)(2)(B)(ii)). On December 30, 2008, the Secretary published a determination in the Federal Register updating the reference code to Standard 90.1-2004 (73 FR 79868).

EPCA also requires the Secretary to permit extensions of the deadlines for the State certification if a State can demonstrate that it has made a good faith effort to comply with the requirements of Section 304(c) of EPCA and that it has made significant progress in doing so (42 U.S.C. 6833(c)).

On September 3, 2010, DOE issued a final positive determination of energy savings for Standard 90.1-2007, which concluded that Standard 90.1-2007 "would achieve greater energy efficiency in buildings subject to the code, than the 2004 edition (Standard 90.1-2004 or the 2004 edition)" (75 FR 54117). Consequently, DOE has determined that Standard 90.1-2007 represents the baseline to which Standard 90.1-2010 requirements are compared for the purpose of a determination of energy savings for Standard 90.1-2010.

This document provides the quantitative (numerical) savings estimate used for DOE's final determination of energy savings for Standard 90.1-2010. The quantitative savings estimate is obtained by simulating a set of prototypical buildings under the requirements of Standard 90.1-2007, then again under Standard 90.1-2010, and then comparing the results. Results are weighted by building type and climate zone to obtain national average estimates. 


\subsection{Determination Process}

DOE typically requests two types of analysis from the BECP in a determination of energy savings for a revised Standard 90.1. The first is a qualitative analysis that attempts to identify all the changes made to the baseline edition of Standard 90.1 to create the revised standard and categorize the changes as having a positive, negative, or neutral impact on energy efficiency in Standard 90.1. No attempt is made to estimate the numerical energy savings either in absolute terms or as a percentage of baseline energy use in the qualitative analysis. Rather, the qualitative analysis discusses qualitatively the significance of each addendum in terms of energy consumption in buildings and whether it appears that the addendum will likely save energy, result in higher energy use, or be largely neutral with regard to energy efficiency. Three steps are typically undertaken in the qualitative analysis. The first step is to identify all changes made to Standard 90.1. The second step is to estimate qualitatively the impact of each change on the energy efficiency of Standard 90.1. The third step is to look at the changes and categorize them into those that have a clear impact on the stringency of requirements in the standard, and of these, those that can or cannot be incorporated in DOE's quantitative analysis.

The second type of analysis that BECP performs for DOE is the quantitative analysis of energy savings of the new edition of Standard 90.1. This analysis uses the results of the qualitative analysis to identify which addenda should be incorporated into the building models used for whole building simulation. These addenda are then reflected as changes in the particular building models to represent compliance with Standard 90.1-2007. .

\subsection{Addenda Included in Standard 90.1-2010}

DOE prepared a qualitative assessment of the addenda to Standard 90.1-2010 and published it as a web document in support of a final assessment of energy savings. ${ }^{1}$ The qualitative analysis contains the complete list of addenda processed by ASHRAE for Standard 90.1-2010. A total of 109 addenda to Standard 90.1-2007 exist. All addenda were applied to ASHRAE Standard 90.1-2007 to create ASHRAE Standard 90.1-2010. ASHRAE/IESNA Standard 90.1-2010 incorporates ASHRAE Standard 90.1-2007 and addenda a, b, c, d, e, f, g, h, I, j, k, l, m, n, o, p, q, r, s, t, u, v, w, x, y, aa, ab, ac, ad, ae, af, ag, ai, aj, ak, al, am, an, ao, ap, aq, ar, as, at, au, av, aw, ax, ay, az, ba, bc, bd, bf, bg, bh, bi, bj, bk, bl, bm, bn, bo, bp, bq, br, bs, bt, bu, bv, bw, bx, by, ca, cb, cc, cd, ce, cf, ch, ck, cl, cn, co, cp, cq, cr, cs, ct, cv, cw, cy, cz, da, db, dc, dd, de, df, dg, di, dj, dk, dl, dn, do, dp, dq, and dr to ASHRAE Standard 90.1-2007. The qualitative analysis lists each addendum and describes how the text of the standard is affected by the change and how that will likely affect the efficiency of new buildings constructed to the standard in the United States. The qualitative analysis also identifies what portion of the standard is affected by the change. ASHRAE Standard 90.1-20010 includes addenda that

- are purely editorial in nature

- update prescriptive design and construction requirements for the envelope, lighting, and mechanical sections of the Standard

\footnotetext{
${ }^{1}$ Pacific Northwest National Laboratory. 2010. ANSI/ASHRAE/IESNA Standard 90.1-2010 Determination Qualitative Analysis. PNNL-20883, Richland, Washington..
} 
- update references to other documents

- update the performance path option to compliance (the energy cost budget [ECB] section of Standard 90.1)

- affect informative appendix material provided in Standard 90.1-2004 but are not part of the construction and design requirements of the Standard.

For the quantitative analysis, DOE incorporated only addenda that modified the prescriptive requirements of the Standard. In specific circumstances, particularly with regard to requirements for certain heating, ventilation, and air-conditioning (HVAC) equipment, addenda to Standard 90.1-2007 reflect changes to national manufacturing standards previously developed by DOE or enacted independently through Federal legislation. Because the energy savings that are attributable to these national manufacturing standards would accrue no matter what edition of Standard 90.1 is considered and regardless of whether they are reflected in the text of the standards, DOE has not incorporated these as changes contributing to energy savings for the purpose of the determination. Table 1 lists all addenda to Standard 90.1-2007 that were incorporated into Standard 90.1-2010. Table 1 is a copy of Appendix F to Standard 90.1-2010 with minor edits to define some of the acronyms used in Appendix F and to ensure that all descriptions follow a similar format. 
Table 1. Addenda to ASHRAE Standard 90.1-2007, Changes Identified

\begin{tabular}{|c|c|c|c|c|c|c|}
\hline Addendum & $\begin{array}{l}\text { Section(s) } \\
\text { Affected }\end{array}$ & Description of Changes & $\begin{array}{c}\text { ASHRAE } \\
\text { Standards } \\
\text { Committee } \\
\text { Approval }\end{array}$ & $\begin{array}{l}\text { ASHRAE } \\
\text { BOD } \\
\text { Approval }\end{array}$ & $\begin{array}{l}\text { IESNA BOD } \\
\text { Approval }\end{array}$ & $\begin{array}{c}\text { ANSI } \\
\text { Approval }\end{array}$ \\
\hline a & $6.8 .1 \mathrm{G}$ & $\begin{array}{l}\text { This addendum seeks to clarify that the current cooling tower } \\
\text { requirements in the Standard apply to open-circuit cooling towers only. }\end{array}$ & $6 / 23 / 2007$ & $6 / 27 / 2007$ & $6 / 12 / 2007$ & $7 / 25 / 2007$ \\
\hline $\mathrm{b}$ & 6.5 .2 .3 & This addendum updates the references for outdoor ventilation rates. & $6 / 23 / 2007$ & $6 / 27 / 2007$ & $6 / 12 / 2007$ & $7 / 25 / 2007$ \\
\hline $\mathrm{c}$ & 6.5.2.3 & $\begin{array}{l}\text { This addendum adds vivariums to the list of spaces that require specific } \\
\text { humidity levels to satisfy process needs. }\end{array}$ & $6 / 23 / 2007$ & $6 / 27 / 2007$ & $6 / 12 / 2007$ & $7 / 25 / 2007$ \\
\hline $\mathrm{d}$ & $5.5 .4 .4,9.7$ & $\begin{array}{l}\text { This addendum modifies the daylighting requirements to allow the use of } \\
\text { photocontrols combined with skylighting to reduce the electricity used } \\
\text { for lighting. }\end{array}$ & $6 / 20 / 2009$ & $6 / 24 / 2009$ & $6 / 15 / 2009$ & $7 / 22 / 2009$ \\
\hline $\mathrm{e}$ & 6.5 .6 & $\begin{array}{l}\text { This addendum modifies the requirements for Energy Recovery by } \\
\text { expanding them to cover the use of energy recovery by weather zone }\end{array}$ & $1 / 23 / 2010$ & $1 / 27 / 2010$ & $1 / 20 / 2010$ & $1 / 28 / 2010$ \\
\hline $\mathrm{f}$ & 5.5 .3 .1 & This addendum sets requirements for high-albedo roofs & $6 / 26 / 2010$ & $6 / 30 / 2010$ & $6 / 23 / 2010$ & $7 / 1 / 2010$ \\
\hline $\mathrm{g}$ & $\begin{array}{l}\text { Section 5, } \\
\text { Normative } \\
\text { Appendix } \\
\text { A2.3 }\end{array}$ & $\begin{array}{l}\text { This addendum updates the building envelope criteria for metal } \\
\text { buildings. }\end{array}$ & $6 / 21 / 2008$ & $6 / 25 / 2008$ & $6 / 30 / 2008$ & $7 / 26 / 2008$ \\
\hline $\mathrm{h}$ & 6.5 .2 .1 & $\begin{array}{l}\text { This addendum adds a new exception that is geared toward zones with } \\
\text { direct digital controls (DDC). }\end{array}$ & $6 / 21 / 2008$ & $6 / 25 / 2008$ & $6 / 30 / 2008$ & $7 / 26 / 2008$ \\
\hline $\mathrm{i}$ & 9.4 .5 & $\begin{array}{l}\text { This addendum applies a four-zone lighting power density approach to } \\
\text { exterior lighting requirements. }\end{array}$ & $6 / 21 / 2008$ & $6 / 25 / 2008$ & $6 / 30 / 2008$ & $7 / 26 / 2008$ \\
\hline $\mathrm{j}$ & $\begin{array}{l}\text { Section } 12, \\
\text { Informative } \\
\text { Appendix E }\end{array}$ & This addendum updates references in the Standard. & $1 / 19 / 2008$ & $1 / 23 / 2008$ & $1 / 28 / 2008$ & $1 / 26 / 2008$ \\
\hline $\mathrm{k}$ & $\begin{array}{l}\text { Table } 6.8 .1 \mathrm{E} \text {, } \\
\text { Table } 7.8\end{array}$ & $\begin{array}{l}\text { This addendum specifies specific sections of reference standards in } \\
\text { Tables } 6.8 .1 \mathrm{E} \text { and } 7.8 \text {. }\end{array}$ & $1 / 19 / 2008$ & $1 / 23 / 2008$ & $1 / 28 / 2008$ & $7 / 24 / 2008$ \\
\hline
\end{tabular}


Table 1. (contd)

\begin{tabular}{|c|c|c|c|c|c|c|}
\hline Addendum & $\begin{array}{l}\text { Section(s) } \\
\text { Affected }\end{array}$ & Description of Changes & $\begin{array}{l}\text { ASHRAE } \\
\text { Standards } \\
\text { Committee } \\
\text { Approval }\end{array}$ & $\begin{array}{l}\text { ASHRAE } \\
\text { BOD } \\
\text { Approval }\end{array}$ & $\begin{array}{l}\text { IESNA } \\
\text { BOD } \\
\text { Approval }\end{array}$ & $\begin{array}{c}\text { ANSI } \\
\text { Approval }\end{array}$ \\
\hline 1 & $\begin{array}{l}\text { Table } 6.8 .1 \mathrm{G} \\
\text { Section } 12\end{array}$ & $\begin{array}{l}\text { This Addendum adds minimum efficiency and certification requirements } \\
\text { for both axial and centrifugal fan closed-circuit cooling towers (also } \\
\text { known as fluid coolers) to Table } 6.8 \text {.1G. In addition, a reference to ATC- } \\
105 \mathrm{~S} \text {, the Cooling Technology Institute test standard for closed-circuit } \\
\text { cooling towers, has been added to Section 12, Normative References. }\end{array}$ & $1 / 19 / 2008$ & $1 / 23 / 2008$ & $1 / 28 / 2008$ & $7 / 24 / 2008$ \\
\hline $\mathrm{m}$ & $\begin{array}{l}\text { Section } \\
\text { 6.4.1.2, Table } \\
\text { 6.8.1C }\end{array}$ & $\begin{array}{l}\text { This addendum establishes effective January } 1,2010 \text {, an additional path } \\
\text { of compliance for water-cooled chillers and also combines all water- } \\
\text { cooled positive displacement chillers into one category and adds a new } \\
\text { size category for centrifugal chillers at or above } 600 \text { tons. }\end{array}$ & $10 / 12 / 2008$ & $10 / 24 / 2008$ & $10 / 10 / 2008$ & $10 / 27 / 2008$ \\
\hline $\mathrm{n}$ & 6.4.3.10 & $\begin{array}{l}\text { This addendum extends variable air volume fan control requirements to } \\
\text { large single-zone units. }\end{array}$ & $6 / 21 / 2008$ & $6 / 25 / 2008$ & $6 / 30 / 2008$ & $7 / 26 / 2008$ \\
\hline o & 8.1 & $\begin{array}{l}\text { This provides the necessary pressure credits for laboratory exhaust } \\
\text { systems that allow prescriptive compliance of systems serving fume } \\
\text { hoods. }\end{array}$ & $6 / 20 / 2009$ & $6 / 24 / 2009$ & $6 / 15 / 2009$ & $7 / 22 / 2009$ \\
\hline $\mathrm{p}$ & 6.5.3.1.1 & $\begin{array}{l}\text { This addendum addresses fan power limitations to all fan systems with } \\
\text { exception to those serving fume hoods. }\end{array}$ & $6 / 21 / 2008$ & $6 / 25 / 2008$ & 6/30/2008 & $7 / 26 / 2008$ \\
\hline $\mathrm{q}$ & 5.4.3.4 & This addendum modifies the vestibule requirements for climate zone 4 . & $1 / 19 / 2008$ & $1 / 23 / 2008$ & $1 / 28 / 2008$ & $7 / 24 / 2008$ \\
\hline $\mathrm{r}$ & Appendix G & $\begin{array}{l}\text { Changes Appendix } \mathrm{G} \text { from an informative appendix to a normative } \\
\text { appendix. }\end{array}$ & 6/6/2009 & 6/24/2009 & 6/15/2009 & $6 / 25 / 2009$ \\
\hline $\mathrm{s}$ & $\begin{array}{l}\text { Table } 6.8 .1 \mathrm{~A}, \\
\text { Table } 6.8 .1 \mathrm{~B}\end{array}$ & $\begin{array}{l}\text { This addendum updates the Coefficient of Performance }(\mathrm{COP}) \text { at } 17^{\circ} \mathrm{F} \\
\text { efficiency levels for commercial heat pumps, and introduces a new part } \\
\text { load energy efficiency descriptor for all commercial unitary products } \\
\text { above } 65,000 \mathrm{Btu} / \mathrm{h} \text { of cooling capacity. }\end{array}$ & $10 / 12 / 2008$ & $10 / 24 / 2008$ & $10 / 10 / 2008$ & $10 / 27 / 2008$ \\
\hline
\end{tabular}


Table 1. (contd)

\begin{tabular}{|c|c|c|c|c|c|c|}
\hline Addendum & $\begin{array}{l}\text { Section(s) } \\
\text { Affected }\end{array}$ & Description of Changes & $\begin{array}{c}\text { ASHRAE } \\
\text { Standards } \\
\text { Committee } \\
\text { Approval }\end{array}$ & $\begin{array}{l}\text { ASHRAE } \\
\text { BOD } \\
\text { Approval }\end{array}$ & $\begin{array}{l}\text { IESNA } \\
\text { BOD } \\
\text { Approval }\end{array}$ & $\begin{array}{c}\text { ANSI } \\
\text { Approval }\end{array}$ \\
\hline $\mathrm{t}$ & $\begin{array}{l}\text { 6.4.1.5.2, } \\
\text { Table 6.8.1D }\end{array}$ & $\begin{array}{l}\text { This addendum removes the terms "replacement" and "new } \\
\text { construction" from the product classes listed in Table } 6.8 .1 \mathrm{D} \text { and } \\
\text { replaces them with the terms "non-standard size" and "standard size," } \\
\text { respectively, to clarify that one product class is intended for applications } \\
\text { with non-standard size exterior wall openings while the other is intended } \\
\text { for applications with standard size exterior wall openings. The } \\
\text { addendum also amends Section } 6.4 .1 .5 .2 \text { and footnote b to Table } 6.8 .1 \mathrm{D} \\
\text { to clarify that non-standard size packaged terminal equipment have } \\
\text { sleeves with an external wall opening less than } 16 \text { in. high or less than } \\
42 \text { in. wide to reflect existing applications where the wall opening is not } \\
\text { necessarily less than } 16 \text { in. high and less than } 42 \text { in. wide. }\end{array}$ & $10 / 12 / 2008$ & $10 / 24 / 2008$ & $10 / 10 / 2008$ & $10 / 27 / 2008$ \\
\hline $\mathrm{u}$ & 6.5.5.3 & $\begin{array}{l}\text { This addendum adds requirements for axial fan open-circuit cooling } \\
\text { towers. }\end{array}$ & $10 / 12 / 2008$ & $10 / 24 / 2008$ & $10 / 10 / 2008$ & $10 / 27 / 2008$ \\
\hline $\mathrm{v}$ & 6.4 .2 & $\begin{array}{l}\text { This addendum modifies the requirements for axial fan open circuit } \\
\text { cooling towers }\end{array}$ & $1 / 24 / 2009$ & $1 / 28 / 2009$ & $1 / 26 / 2009$ & $1 / 29 / 2009$ \\
\hline $\mathrm{w}$ & $\begin{array}{l}\text { Table } \\
\text { G3.1.1A, } \\
\text { Section } \\
\text { G3.1.2.10 }\end{array}$ & $\begin{array}{l}\text { This addendum modifies requirements on exhaust air energy recovery } \\
\text { for multifamily buildings in Appendix G. }\end{array}$ & $10 / 12 / 2008$ & $10 / 24 / 2008$ & $10 / 10 / 2008$ & $10 / 27 / 2008$ \\
\hline $\mathrm{x}$ & 9.4.1.1 & $\begin{array}{l}\text { Updates the requirements for automatic lighting shutoffs, adds specific } \\
\text { occupancy sensor applications, and provides additional clarification. }\end{array}$ & 6/20/2009 & $6 / 24 / 2009$ & $6 / 15 / 2009$ & $7 / 22 / 2009$ \\
\hline $\mathrm{y}$ & $\begin{array}{l}\text { Table } 7.8 \\
\text { Section } 12\end{array}$ & $\begin{array}{l}\text { This addendum establishes ARI } 1160 \text { as the test procedure for heat pump } \\
\text { pool heaters and that the minimum COP be met at the low outdoor } \\
\text { temperature of } 50^{\circ} \mathrm{F} \text {. }\end{array}$ & $6 / 21 / 2008$ & $6 / 25 / 2008$ & $6 / 30 / 2008$ & $7 / 26 / 2008$ \\
\hline aa & 9.4 .1 & $\begin{array}{l}\text { This change mandates that lighting controls have a "manual on" } \\
\text { capability }\end{array}$ & $6 / 20 / 2009$ & $6 / 24 / 2009$ & $6 / 15 / 2009$ & $7 / 22 / 2009$ \\
\hline$a b$ & 9.4 .1 & $\begin{array}{l}\text { This change modifies skylighting and daylighting requirements from } \\
\text { addendum "d" to } 90.1-2007 \text {. }\end{array}$ & 6/20/2009 & $6 / 24 / 2009$ & $6 / 15 / 2009$ & $7 / 22 / 2009$ \\
\hline
\end{tabular}


Table 1. (contd)

\begin{tabular}{|c|c|c|c|c|c|c|}
\hline Addendum & $\begin{array}{l}\text { Section(s) } \\
\text { Affected }\end{array}$ & Description of Changes & $\begin{array}{l}\text { ASHRAE } \\
\text { Standards } \\
\text { Committee } \\
\text { Approval }\end{array}$ & $\begin{array}{l}\text { ASHRAE } \\
\text { BOD } \\
\text { Approval }\end{array}$ & $\begin{array}{l}\text { IESNA } \\
\text { BOD } \\
\text { Approval }\end{array}$ & $\begin{array}{c}\text { ANSI } \\
\text { Approval }\end{array}$ \\
\hline ac & $9.1 .4,9.6 .2$ & $\begin{array}{l}\text { This addendum modifies requirements for controls in the following } \\
\text { applications: personal and manual dimming, multi-scene, manual and } \\
\text { automatic bi-level switching, daylighting. }\end{array}$ & $6 / 21 / 2008$ & $6 / 25 / 2008$ & $6 / 30 / 2008$ & $7 / 24 / 2008$ \\
\hline $\mathrm{ad}$ & $\begin{array}{l}\text { Table } 6.8 .1 \mathrm{~K} \\
\text { Section } \\
6.4 .1 .4 \\
\text { Section } 12\end{array}$ & $\begin{array}{l}\text { This addendum adds requirements for liquid to liquid heat exchangers } \\
\text { and adds a reference to AHRI } 400-2008 \text {. }\end{array}$ & $6 / 21 / 2008$ & $6 / 25 / 2008$ & $6 / 30 / 2008$ & $7 / 24 / 2008$ \\
\hline ae & 6.4.4.1.4 & Adds requirements for radiant heating panels. & $6 / 20 / 2009$ & $6 / 24 / 2009$ & $6 / 15 / 2009$ & $7 / 22 / 2009$ \\
\hline af & 6.5.4.5 & Modifies the pipe sizing requirements. & $1 / 24 / 2009$ & $1 / 28 / 2009$ & $1 / 26 / 2009$ & $1 / 29 / 2009$ \\
\hline ag & 5.8.1.10 & Adds a requirement for joint insulation overlap. & 6/6/2009 & $6 / 24 / 2009$ & $6 / 15 / 2009$ & $6 / 25 / 2009$ \\
\hline ai & G3.1.1.3 & $\begin{array}{l}\text { Clarifies how distribution pump energy is to be addressed when using } \\
\text { purchased heat or purchased chilled water. }\end{array}$ & $6 / 6 / 2009$ & $6 / 24 / 2009$ & $6 / 15 / 2009$ & $6 / 25 / 2009$ \\
\hline aj & 10.4 .1 & $\begin{array}{l}\text { Updates the test and table of Chapter } 10 \text { to comply with the new federal } \\
\text { law. Since the new law and the new version of ASHRAE } 90.1 \text { will both } \\
\text { occur in } 2010 \text {, this change will ensure that there is no confusion about } \\
\text { the new energy efficiency standards for motors that are manufactured in } \\
2010 \text { and beyond. }\end{array}$ & $6 / 6 / 2009$ & $6 / 24 / 2009$ & $6 / 15 / 2009$ & $6 / 25 / 2009$ \\
\hline ak & 6.5 .4 & $\begin{array}{l}\text { Modifies requirements for Heat Pump and Water-Cooled Unitary Air- } \\
\text { Conditioners, Differential Pressure Reset, fan power limitations, chilled } \\
\text { water cooling, and deletion of } 10 \mathrm{hp} \text { (horsepower) from Section 6.5.4 }\end{array}$ & 6/6/2009 & $6 / 24 / 2009$ & $6 / 15 / 2009$ & $6 / 25 / 2009$ \\
\hline al & 5.5.4.2.3 & $\begin{array}{l}\text { Adds skylight requirements in certain space types to promote daylighting } \\
\text { energy savings. }\end{array}$ & $6 / 26 / 2010$ & $6 / 30 / 2010$ & $6 / 23 / 2010$ & $7 / 1 / 2010$ \\
\hline $\mathrm{am}$ & 5.4.3.2 & $\begin{array}{l}\text { The intent of this addendum is to revise air leakage criteria so they more } \\
\text { closely reflect current practice. }\end{array}$ & $6 / 26 / 2010$ & $6 / 30 / 2010$ & $6 / 23 / 2010$ & $7 / 1 / 2010$ \\
\hline an & $\begin{array}{l}\text { Appendix } \\
\text { A2.4 }\end{array}$ & $\begin{array}{l}\text { This addendum expands the table of default U-Factors for single digit } \\
\text { rafter roofs. }\end{array}$ & $1 / 24 / 2009$ & $1 / 28 / 2009$ & $1 / 26 / 2009$ & $1 / 29 / 2009$ \\
\hline
\end{tabular}


Table 1. (contd)

\begin{tabular}{|c|c|c|c|c|c|c|}
\hline Addendum & $\begin{array}{l}\text { Section(s) } \\
\text { Affected }\end{array}$ & Description of Changes & $\begin{array}{l}\text { ASHRAE } \\
\text { Standards } \\
\text { Committee } \\
\text { Approval }\end{array}$ & $\begin{array}{l}\text { ASHRAE } \\
\text { BOD } \\
\text { Approval }\end{array}$ & $\begin{array}{l}\text { IESNA } \\
\text { BOD } \\
\text { Approval }\end{array}$ & $\begin{array}{c}\text { ANSI } \\
\text { Approval }\end{array}$ \\
\hline ao & Table 6.8.1E & $\begin{array}{l}\text { Corrects errors in Table 6.8.1E, re-orders footnotes, and changes one } \\
\text { efficiency. }\end{array}$ & $1 / 24 / 2009$ & $1 / 28 / 2009$ & $1 / 26 / 2009$ & $1 / 29 / 2009$ \\
\hline ap & 6.3 .2 & Modifies the requirements for Demand Control Ventilation (DCV). & $1 / 24 / 2009$ & $1 / 28 / 2009$ & $1 / 26 / 2009$ & $1 / 29 / 2009$ \\
\hline aq & $\begin{array}{l}\text { 1. Purpose, } 2 . \\
\text { Scope }\end{array}$ & $\begin{array}{l}\text { This addendum modifies the Purpose Title and expands the Scope of } \\
\text { ASHRAE Standard } 90.1 \text { so the standard may regulate process loads }\end{array}$ & $6 / 26 / 2010$ & $6 / 30 / 2010$ & $6 / 23 / 2010$ & $7 / 1 / 2010$ \\
\hline ar & $9.1 .3,9.4 .5$ & This addendum adds exterior lighting power requirements. & $1 / 23 / 2010$ & $1 / 27 / 2010$ & $1 / 20 / 2010$ & $1 / 24 / 2010$ \\
\hline as & 6.5.2.1 & This addendum adds lab exhaust requirements. & $1 / 23 / 2010$ & $1 / 27 / 2010$ & $1 / 20 / 2010$ & $1 / 28 / 2010$ \\
\hline at & 6.4.3.4 & This change modifies the exhaust air damper requirements in 90.1 & $6 / 20 / 2009$ & $6 / 24 / 2009$ & $6 / 15 / 2009$ & $7 / 22 / 2009$ \\
\hline $\mathrm{au}$ & 6.3 .2 & This change modifies the economizer requirements in Standard 90.1. & $6 / 20 / 2009$ & $6 / 24 / 2009$ & $6 / 15 / 2009$ & $7 / 22 / 2009$ \\
\hline av & 9.1.2.1 & $\begin{array}{l}\text { This modifies the requirements of section 9.1.2 Lighting Alterations and } \\
\text { replaces the previous public review draft of addendum "av" in its } \\
\text { entirety. }\end{array}$ & $1 / 23 / 2010$ & $1 / 27 / 2010$ & $1 / 20 / 2010$ & $1 / 24 / 2010$ \\
\hline aw & 9.4.1.4 & $\begin{array}{l}\text { This change recognizes the practical design application of excluding } \\
\text { bathroom lighting from "master" switch control in hotel/motel guest } \\
\text { rooms and adds a requirement to eliminate wasted light in guest room } \\
\text { bathrooms. }\end{array}$ & $1 / 19 / 2008$ & $1 / 23 / 2008$ & $1 / 28 / 2008$ & $7 / 26 / 2008$ \\
\hline ax & 6.5.7.1 & This modifies requirements for kitchen exhaust. & $6 / 26 / 2010$ & $6 / 30 / 2010$ & $6 / 23 / 2010$ & $7 / 1 / 2010$ \\
\hline ay & 9.6 .1 & $\begin{array}{l}\text { This change requires users to identify spaces by function and is } \\
\text { consistent with a previous interpretation. It is expected that the net } \\
\text { energy result will be positive. }\end{array}$ & $6 / 6 / 2009$ & $6 / 24 / 2009$ & $6 / 15 / 2009$ & $6 / 25 / 2009$ \\
\hline $\mathrm{az}$ & 9.4 .6 & $\begin{array}{l}\text { Lighting controls must be functionally tested to ensure their proper use } \\
\text { and appropriate energy savings. This addendum provides requirements } \\
\text { for those tests. }\end{array}$ & $1 / 23 / 2010$ & $1 / 27 / 2010$ & $1 / 20 / 2010$ & $1 / 28 / 2010$ \\
\hline ba & 6.8 .3 & $\begin{array}{l}\text { This addendum adds system performance option that allows } \\
\text { compensating for the insulating value of the piping while maintaining } \\
\text { the same net thermal requirements. }\end{array}$ & $6 / 20 / 2009$ & $6 / 24 / 2009$ & $6 / 15 / 2009$ & $7 / 22 / 2009$ \\
\hline
\end{tabular}


Table 1. (contd)

\begin{tabular}{|c|c|c|c|c|c|c|}
\hline Addendum & $\begin{array}{l}\text { Section(s) } \\
\text { Affected }\end{array}$ & Description of Changes & $\begin{array}{l}\text { ASHRAE } \\
\text { Standards } \\
\text { Committee } \\
\text { Approval }\end{array}$ & $\begin{array}{l}\text { ASHRAE } \\
\text { BOD } \\
\text { Approval }\end{array}$ & $\begin{array}{l}\text { IESNA } \\
\text { BOD } \\
\text { Approval }\end{array}$ & $\begin{array}{c}\text { ANSI } \\
\text { Approval }\end{array}$ \\
\hline $\mathrm{bc}$ & 5.1.2.2 & $\begin{array}{l}\text { This clarifies that the requirements in Section 5.5.4.2.3 are also specified } \\
\text { for unconditioned spaces. }\end{array}$ & $6 / 6 / 2009$ & $6 / 24 / 2009$ & $6 / 15 / 2009$ & $6 / 25 / 2009$ \\
\hline bd & 8.4 .1 & $\begin{array}{l}\text { This addendum removes emergency circuits not used for normal } \\
\text { building operation from the requirements which will lead to increased } \\
\text { compliance. }\end{array}$ & $6 / 6 / 2009$ & $6 / 24 / 2009$ & $6 / 15 / 2009$ & $6 / 25 / 2009$ \\
\hline bf & 5.4.3.1 & $\begin{array}{l}\text { This provides performance requirements for air leakage of the opaque } \\
\text { envelope. }\end{array}$ & $6 / 26 / 2010$ & $6 / 30 / 2010$ & $6 / 23 / 2010$ & $7 / 1 / 2010$ \\
\hline bg & Table 6.8.1B & This provides requirements for water-to-water heat pumps. & $1 / 23 / 2010$ & $1 / 27 / 2010$ & $1 / 20 / 2010$ & $1 / 28 / 2010$ \\
\hline bh & 6.5.3.3 & $\begin{array}{l}\text { This addendum provides requirements for multiple zone HVAC systems } \\
\text { (that include simultaneous heating and cooling) to include controls that } \\
\text { automatically raise the supply-air temperature when the spaces served } \\
\text { are not at peak load conditions. }\end{array}$ & $1 / 23 / 2010$ & $1 / 27 / 2010$ & $1 / 20 / 2010$ & $1 / 28 / 2010$ \\
\hline bi & 6.4.4.1.3 & This addendum provides updated requirements for pipe insulation. & $6 / 26 / 2010$ & $6 / 30 / 2010$ & $6 / 23 / 2010$ & $7 / 1 / 2010$ \\
\hline bj & G3.1.2.5 & $\begin{array}{l}\text { This addendum adds an exception within Appendix } G \text { that allows users } \\
\text { to claim energy cost savings credit for the increased ventilation } \\
\text { effectiveness of certain HVAC system designs. }\end{array}$ & $1 / 23 / 2010$ & $1 / 27 / 2010$ & $1 / 20 / 2010$ & $1 / 28 / 2010$ \\
\hline bk & 10.4 .1 & $\begin{array}{l}\text { This addendum distinguishes Subtype I and Subtype II motors. } \\
\text { Addendum aj to ASHRAE Standard } 90.1-2007 \text { first incorporated these } \\
\text { changes into Standard } 90.1 \text {. This proposed language has different } \\
\text { minimum efficiency requirements as called out in EISA 2007, Section } \\
313 \text { and clarified in the Federal Register. }\end{array}$ & $1 / 23 / 2010$ & $1 / 27 / 2010$ & $1 / 20 / 2010$ & $1 / 28 / 2010$ \\
\hline $\mathrm{bl}$ & 6.4.1.2.1 & $\begin{array}{l}\text { This addendum adds requirements for chillers with secondary coolants } \\
\text { (glycol or brine). In additions, there are changes to footnote a to Table } \\
6.8 .1 \mathrm{C} \text { in recognition of lower practical scope limits for positive } \\
\text { displacement (both air- and water-cooled) and corrects for the lower } \\
\text { limit introduced in Addendum M for centrifugal chillers. }\end{array}$ & $1 / 23 / 2010$ & $1 / 27 / 2010$ & $1 / 20 / 2010$ & $1 / 28 / 2010$ \\
\hline $\mathrm{bm}$ & 3.3 & $\begin{array}{l}\text { The intent of this addendum is to coordinate terminology for visible } \\
\text { transmittance with NFRC } 200\end{array}$ & $1 / 23 / 2010$ & $1 / 27 / 2010$ & $1 / 20 / 2010$ & $1 / 28 / 2010$ \\
\hline
\end{tabular}


Table 1. (contd)

\begin{tabular}{|c|c|c|c|c|c|c|}
\hline Addendum & $\begin{array}{c}\text { Section(s) } \\
\text { Affected }\end{array}$ & Description of Changes & $\begin{array}{l}\text { ASHRAE } \\
\text { Standards } \\
\text { Committee } \\
\text { Approval }\end{array}$ & $\begin{array}{l}\text { ASHRAE } \\
\text { BOD } \\
\text { Approval }\end{array}$ & $\begin{array}{l}\text { IESNA } \\
\text { BOD } \\
\text { Approval }\end{array}$ & $\begin{array}{c}\text { ANSI } \\
\text { Approval }\end{array}$ \\
\hline bn & 5.5.4.5 & $\begin{array}{l}\text { This addendum limits poorly oriented fenestration. Compliance can be } \\
\text { shown by having more south facing fenestration than west facing } \\
\text { fenestration. For those buildings affected by this requirement, this } \\
\text { reduces envelope loads, energy usage and thereby costs }\end{array}$ & $6 / 26 / 2010$ & $6 / 30 / 2010$ & $6 / 23 / 2010$ & $7 / 1 / 2010$ \\
\hline bo & $\begin{array}{l}\text { 11.3.2, } \\
\text { G3.1.2.1 }\end{array}$ & $\begin{array}{l}\text { This addendum is part of an ongoing effort to keep the requirements of } \\
\text { Section } 11 \text { and Appendix } G \text { consistent with other addenda to the } \\
\text { Standard. This addendum makes changes to Section } 11 \text { and } G \text { related to } \\
\text { Addenda e, s, and u }\end{array}$ & $1 / 23 / 2010$ & $1 / 27 / 2010$ & $1 / 20 / 2010$ & $1 / 28 / 2010$ \\
\hline $\mathrm{bp}$ & 9.4 .1 & $\begin{array}{l}\text { This addendum allows the use of control that provides automatic } 50 \% \\
\text { auto-on with the capability to manually activate the remaining } 50 \% \text { and } \\
\text { has full auto-off. }\end{array}$ & $1 / 23 / 2010$ & $1 / 27 / 2010$ & $1 / 20 / 2010$ & $1 / 24 / 2010$ \\
\hline $\mathrm{bq}$ & 9.6 .2 & $\begin{array}{l}\text { This addendum changes the requirements for retail space lighting which } \\
\text { will make use of more recent lamp technology that is readily available. }\end{array}$ & $1 / 23 / 2010$ & $1 / 27 / 2010$ & $1 / 20 / 2010$ & $1 / 28 / 2010$ \\
\hline br & 9.4 .5 & $\begin{array}{l}\text { This addendum adds an exterior zone } 0 \text { to cover very low light } \\
\text { requirement areas }\end{array}$ & $1 / 23 / 2010$ & $1 / 27 / 2010$ & $1 / 20 / 2010$ & $1 / 28 / 2010$ \\
\hline bs & 8.4 .2 & $\begin{array}{l}\text { This new requirement will provide the means for non-critical receptacle } \\
\text { loads to be automatically controlled (turned off) based on occupancy or } \\
\text { scheduling without additional individual desk top or similar controllers. }\end{array}$ & $6 / 26 / 2010$ & $6 / 30 / 2010$ & $6 / 23 / 2010$ & $7 / 1 / 2010$ \\
\hline bt & 6.4.1.2 & $\begin{array}{l}\text { This addendum modifies centrifugal chiller adjustment factor for } \\
\text { nonstandard conditions. }\end{array}$ & $6 / 26 / 2010$ & $6 / 30 / 2010$ & $6 / 23 / 2010$ & 7/1/2010 \\
\hline bu & $\begin{array}{l}\text { 6.4.1.1, 6.5.1, } \\
\text { table } 6.8 .1 \mathrm{H}\end{array}$ & $\begin{array}{l}\text { This addendum adds efficiency requirements to HVAC systems } \\
\text { dedicated to computer rooms and data centers. }\end{array}$ & $7 / 20 / 2010$ & $7 / 23 / 2010$ & $7 / 24 / 2010$ & $7 / 26 / 2010$ \\
\hline bv & G3.1.2.9 & $\begin{array}{l}\text { This addendum makes Appendix G of Standard } 90.1 \text { consistent with } \\
\text { addenda aj, bk, and ax. }\end{array}$ & $1 / 23 / 2010$ & $1 / 27 / 2010$ & $1 / 20 / 2010$ & $1 / 28 / 2010$ \\
\hline bw & Table 6.8.1D & $\begin{array}{l}\text { This addendum modifies efficiency requirements for packaged terminal } \\
\text { air conditioner (PTAC). }\end{array}$ & $1 / 23 / 2010$ & $1 / 27 / 2010$ & $1 / 20 / 2010$ & $1 / 28 / 2010$ \\
\hline bx & 6.5 .2 .1 & $\begin{array}{l}\text { This addendum modifies Variable Air Volume (VAV) reheat } \\
\text { requirements. }\end{array}$ & $6 / 26 / 2010$ & $6 / 30 / 2010$ & $6 / 23 / 2010$ & $7 / 1 / 2010$ \\
\hline
\end{tabular}


Table 1. (contd)

\begin{tabular}{|c|c|c|c|c|c|c|}
\hline Addendum & $\begin{array}{c}\text { Section(s) } \\
\text { Affected }\end{array}$ & Description of Changes & $\begin{array}{c}\text { ASHRAE } \\
\text { Standards } \\
\text { Committee } \\
\text { Approval }\end{array}$ & $\begin{array}{l}\text { ASHRAE } \\
\text { BOD } \\
\text { Approval }\end{array}$ & $\begin{array}{l}\text { IESNA } \\
\text { BOD } \\
\text { Approval }\end{array}$ & $\begin{array}{c}\text { ANSI } \\
\text { Approval }\end{array}$ \\
\hline by & $\begin{array}{l}\text { 9.6.2, Table } \\
9.5 .1\end{array}$ & $\begin{array}{l}\text { Proposes new Lighting Power Densities for both the whole building and } \\
\text { space-by-space compliance methods. In addition, the Lighting Power } \\
\text { Density may be re-calculated based on room geometry. }\end{array}$ & $6 / 26 / 2010$ & $6 / 30 / 2010$ & $6 / 23 / 2010$ & $7 / 1 / 2010$ \\
\hline $\mathrm{ca}$ & 6.5 .3 .1 .1 & $\begin{array}{l}\text { Closes a loophole in the fan power allowances for VAV systems. } \\
\text { Standard VAV systems are multi-zone systems with terminal units } \\
\text { containing control dampers to vary airflow to individual zone }\end{array}$ & $6 / 26 / 2010$ & $6 / 30 / 2010$ & $6 / 23 / 2010$ & $7 / 1 / 2010$ \\
\hline $\mathrm{cb}$ & $\begin{array}{l}\text { 6.3.2, } \\
6.4 .3 .4 .2\end{array}$ & $\begin{array}{l}\text { This addendum includes a number of changes to require simple systems } \\
\text { to meet prescriptive outdoor air damper requirements, allow backdraft } \\
\text { dampers only for exhaust and relief dampers in buildings less than three } \\
\text { stories in height, require backdraft dampers on outdoor air intakes to be } \\
\text { protected from wind limiting windblown infiltration through the damper. }\end{array}$ & $6 / 26 / 2010$ & $6 / 30 / 2010$ & $6 / 23 / 2010$ & $7 / 1 / 2010$ \\
\hline $\mathrm{cc}$ & Table 6.5.4.5 & $\begin{array}{l}\text { This addendum corrects the way } 8 \text { " pipe was analyzed. RS Means data } \\
\text { for threaded pipe was used for } 8 \text { " when welded pipe data should have } \\
\text { been used. It also includes a minor editorial change since it is not } \\
\text { possible to operate more than } 8760 \mathrm{hr} / \mathrm{yr} \text {. }\end{array}$ & $6 / 26 / 2010$ & $6 / 30 / 2010$ & $6 / 23 / 2010$ & $7 / 1 / 2010$ \\
\hline $\mathrm{cd}$ & 9.4 & $\begin{array}{l}\text { Additions to 1) strengthen the language to actually require exterior } \\
\text { control rather than just require the control capability; 2) add bi-level } \\
\text { control for general all-night applications such as parking lots to reduce } \\
\text { lighting when not needed; } 3 \text { ) add control for façade and landscaping } \\
\text { lighting not needed after midnight. }\end{array}$ & $7 / 20 / 2010$ & $7 / 23 / 2010$ & $7 / 24 / 2010$ & $7 / 26 / 2010$ \\
\hline ce & 9.4.1.2 & $\begin{array}{l}\text { Adds requirements that all spaces (unless exempted) have multilevel } \\
\text { control capability (also commonly known as bi-level switching). }\end{array}$ & $6 / 26 / 2010$ & $6 / 30 / 2010$ & $6 / 23 / 2010$ & $7 / 1 / 2010$ \\
\hline $\mathrm{cf}$ & 9.4.1.4 & $\begin{array}{l}\text { Adds requirements for automatic reduction of stairway lighting within } \\
\text { thirty minutes of occupants exiting the zone. }\end{array}$ & $7 / 20 / 2010$ & $7 / 23 / 2010$ & $7 / 24 / 2010$ & $7 / 26 / 2010$ \\
\hline $\mathrm{ch}$ & 11.3.2, G3.1.1 & $\begin{array}{l}\text { This addendum makes Appendix } \mathrm{G} \text { and Section } 11 \text { consistent with } \\
\text { requirements approved in Addenda } \mathrm{h} \text { (dual minimum controls) and as } \\
\text { (lab exhaust). }\end{array}$ & $6 / 26 / 2010$ & $6 / 30 / 2010$ & $6 / 23 / 2010$ & $7 / 1 / 2010$ \\
\hline ck & 6.5 .3 & $\begin{array}{l}\text { This addendum expands zone level demand controlled ventilation to } \\
\text { include various forms of system level strategies. }\end{array}$ & $7 / 20 / 2010$ & $7 / 23 / 2010$ & $7 / 24 / 2010$ & $7 / 26 / 2010$ \\
\hline
\end{tabular}


Table 1. (contd)

\begin{tabular}{|c|c|c|c|c|c|c|}
\hline Addendum & $\begin{array}{c}\text { Section(s) } \\
\text { Affected }\end{array}$ & Description of Changes & $\begin{array}{l}\text { ASHRAE } \\
\text { Standards } \\
\text { Committee } \\
\text { Approval }\end{array}$ & $\begin{array}{l}\text { ASHRAE } \\
\text { BOD } \\
\text { Approval }\end{array}$ & $\begin{array}{l}\text { IESNA } \\
\text { BOD } \\
\text { Approval }\end{array}$ & $\begin{array}{c}\text { ANSI } \\
\text { Approval }\end{array}$ \\
\hline $\mathrm{cl}$ & $\begin{array}{l}\text { 5.5.4.4.2, } \\
\text { Appendix C }\end{array}$ & $\begin{array}{l}\text { The proposed text would clarify how to interpret the use of dynamic } \\
\text { glazing products that are designed to be able to vary a performance } \\
\text { property such as Solar Heat Gain Coefficient (SHGC), rather than } \\
\text { having just a single value. }\end{array}$ & $6 / 26 / 2010$ & $6 / 30 / 2010$ & $6 / 23 / 2010$ & $7 / 1 / 2010$ \\
\hline $\mathrm{cn}$ & Table 9.6.2 & $\begin{array}{l}\text { Adds two versions of a combined advanced control to the control } \\
\text { incentives table. These control system combinations involve personal } \\
\text { workstation control and workstation-specific occupancy sensors for open } \\
\text { office applications. The control incentive will apply only to the } \\
\text { particular controls when they are applied in open office areas. }\end{array}$ & $7 / 20 / 2010$ & $7 / 23 / 2010$ & $7 / 24 / 2010$ & $7 / 26 / 2010$ \\
\hline co & Table 6.8.1A & $\begin{array}{l}\text { This proposal makes three major amendments to Table 6.8.1A. First, it } \\
\text { updates Energy Efficiency Ratio (EER) and Integrated Energy } \\
\text { Efficiency Ratio (IEER) values for all condensing units and water and } \\
\text { evaporatively cooled air conditioners with cooling capacities greater than } \\
65,000 \text { Btu/h. Second, the proposal establishes a separate product class } \\
\text { for evaporatively cooled air conditioners with different energy efficiency } \\
\text { standards. Third, the proposal replaces the Integrated Partial Load Value } \\
\text { (IPLV) descriptor for condensing units with the new IEER metric and } \\
\text { amends the EERs with more stringent values. }\end{array}$ & 7/20/2010 & $7 / 23 / 2010$ & $7 / 24 / 2010$ & $7 / 26 / 2010$ \\
\hline $\mathrm{cp}$ & $\begin{array}{l}\text { 6.4.1.1, Table } \\
\text { 6.8.1L }\end{array}$ & $\begin{array}{l}\text { This addendum establishes, for the first time in ASHRAE 90.1, } \\
\text { efficiency requirements for Variable Refrigerant Flow (VRF) air } \\
\text { conditioners and heat pumps, including heat pumps that use a water } \\
\text { source for heat rejection. }\end{array}$ & $6 / 26 / 2010$ & $6 / 30 / 2010$ & $6 / 23 / 2010$ & $7 / 1 / 2010$ \\
\hline $\mathrm{cq}$ & 6.4.4.2 & $\begin{array}{l}\text { This addendum modifies the duct sealing requirements in } \\
\text { ANSI/ASHRAE/IESNA Standard 90.1-2007. }\end{array}$ & 7/20/2010 & $7 / 23 / 2010$ & $7 / 24 / 2010$ & $7 / 26 / 2010$ \\
\hline
\end{tabular}


Table 1. (contd)

\begin{tabular}{|c|c|c|c|c|c|c|}
\hline Addendum & $\begin{array}{l}\text { Section(s) } \\
\text { Affected }\end{array}$ & Description of Changes & $\begin{array}{l}\text { ASHRAE } \\
\text { Standards } \\
\text { Committee } \\
\text { Approval }\end{array}$ & $\begin{array}{l}\text { ASHRAE } \\
\text { BOD } \\
\text { Approval }\end{array}$ & $\begin{array}{l}\text { IESNA } \\
\text { BOD } \\
\text { Approval }\end{array}$ & $\begin{array}{l}\text { ANSI } \\
\text { Approval }\end{array}$ \\
\hline $\mathrm{cr}$ & $\begin{array}{l}\text { table } 11.3 .1 \\
\text { Appendix } \mathrm{G}\end{array}$ & $\begin{array}{l}\text { Modifies definition of unmet load hour. It is currently lacking a } \\
\text { throttling range or limit to the setpoint. It was decided that the baseline } \\
\text { and proposed shall have the same thermostat throttling range. This } \\
\text { required additional language in the unmet load hour definition as to how } \\
\text { throttling range effects determination of an unmet hour along with } \\
\text { additional language in Table } 11.3 .1 \text { and Table G3.1, Design Model } \\
\text { sections. }\end{array}$ & $6 / 26 / 2010$ & $6 / 30 / 2010$ & $6 / 23 / 2010$ & $7 / 1 / 2010$ \\
\hline cs & 8.4 .2 & $\begin{array}{l}\text { Modifies automatic receptacle control requirements and exemptions to } \\
\text { eliminate potential practical application issues. }\end{array}$ & $6 / 26 / 2010$ & $6 / 30 / 2010$ & $6 / 23 / 2010$ & $7 / 1 / 2010$ \\
\hline ct & 9.4 .1 .3 & $\begin{array}{l}\text { This addendum sets controls for the "night lights" that are part of the } \\
\text { emergency system when there are no occupants in the space. This has } \\
\text { definite energy savings and is not prohibited by the electrical codes. }\end{array}$ & $7 / 20 / 2010$ & $7 / 23 / 2010$ & $7 / 24 / 2010$ & $7 / 26 / 2010$ \\
\hline $\mathrm{cV}$ & 10.4 .2 & $\begin{array}{l}\text { This addendum adds energy efficiency requirements for service water } \\
\text { pressure booster systems. }\end{array}$ & $7 / 20 / 2010$ & $7 / 23 / 2010$ & $7 / 24 / 2010$ & $7 / 26 / 2010$ \\
\hline $\mathrm{cw}$ & 11.3 .1 & $\begin{array}{l}\text { Addresses corrections and clarifications necessary to Section 11, } \\
\text { Table 11.3.1 and Section } 11 \text { Service Hot Water Systems. }\end{array}$ & $6 / 26 / 2010$ & $6 / 30 / 2010$ & $6 / 23 / 2010$ & $7 / 1 / 2010$ \\
\hline cy & 6.5 .1 & $\begin{array}{l}\text { This addendum makes several revisions to the economizer requirements } \\
\text { in Section } 6.5 .1 \text { and in Section 6.3.2. With increased envelope insulation } \\
\text { levels and higher internal plug loads we are seeing commercial buildings } \\
\text { operating in cooling at lower ambient temperatures. This allows for } \\
\text { greater air and water economizers to be used instead of mechanical } \\
\text { cooling. }\end{array}$ & $7 / 20 / 2010$ & $7 / 23 / 2010$ & $7 / 24 / 2010$ & $7 / 26 / 2010$ \\
\hline $\mathrm{cz}$ & 9.4.1.3 & $\begin{array}{l}\text { Incorporates bi-level control for parking garages to reduce the wasted } \\
\text { energy associated with unoccupied periods for many garages AND } \\
\text { allows an exception for lighting in the transition (entrance/exit) areas to } \\
\text { accommodate IES recommendations. }\end{array}$ & $6 / 26 / 2010$ & $6 / 30 / 2010$ & $6 / 23 / 2010$ & $7 / 1 / 2010$ \\
\hline $\mathrm{da}$ & G3.1.2.5 & $\begin{array}{l}\text { Establishes that an Appendix } G \text { baseline shall be based on the minimum } \\
\text { ventilation requirements required by local codes or a rating authority and } \\
\text { not the proposed design ventilation rates. }\end{array}$ & $6 / 26 / 2010$ & $6 / 30 / 2010$ & $6 / 23 / 2010$ & $7 / 1 / 2010$ \\
\hline
\end{tabular}


Table 1. (contd)

\begin{tabular}{|c|c|c|c|c|c|c|}
\hline Addendum & $\begin{array}{l}\text { Section(s) } \\
\text { Affected }\end{array}$ & Description of Changes & $\begin{array}{l}\text { ASHRAE } \\
\text { Standards } \\
\text { Committee } \\
\text { Approval }\end{array}$ & $\begin{array}{l}\text { ASHRAE } \\
\text { BOD } \\
\text { Approval }\end{array}$ & $\begin{array}{l}\text { IESNA } \\
\text { BOD } \\
\text { Approval }\end{array}$ & $\begin{array}{c}\text { ANSI } \\
\text { Approval }\end{array}$ \\
\hline $\mathrm{db}$ & G3.1.2 & $\begin{array}{l}\text { This addendum modifies the fan power requirements in the energy cost } \\
\text { budget section. }\end{array}$ & $7 / 20 / 2010$ & $7 / 23 / 2010$ & $7 / 24 / 2010$ & $7 / 26 / 2010$ \\
\hline dc & 9.4 .2 & $\begin{array}{l}\text { The conditions and common practice that existed to create the need for } \\
\text { this requirement on tandem wiring are no longer practiced primarily with } \\
\text { the new Federal efficacy requirements and products available on the } \\
\text { market. Therefore, removes information related to tandem wiring of } \\
\text { lighting. }\end{array}$ & $6 / 26 / 2010$ & $6 / 30 / 2010$ & $6 / 23 / 2010$ & $7 / 1 / 2010$ \\
\hline dd & 5.5.4.2.3 & This addendum modifies the VAV fan power limitation requirements. & $7 / 20 / 2010$ & $7 / 23 / 2010$ & $7 / 24 / 2010$ & $7 / 26 / 2010$ \\
\hline de & Table 9.6.1 & $\begin{array}{l}\text { This addendum lowers the Lighting Power Densities in Standard } 90.1 \text { to } \\
\text { reflect advances in lighting technology. }\end{array}$ & $7 / 20 / 2010$ & $7 / 23 / 2010$ & $7 / 24 / 2010$ & $7 / 26 / 2010$ \\
\hline df & 10.4 .3 & $\begin{array}{l}\text { This addendum sets requirements for elevator ventilation and lighting, } \\
\text { which have been unregulated, regardless of occupancy. }\end{array}$ & $7 / 20 / 2010$ & $7 / 23 / 2010$ & $7 / 24 / 2010$ & $7 / 26 / 2010$ \\
\hline $\mathrm{dg}$ & Table G3.1 & $\begin{array}{l}\text { This addendum adds a definition for the term "field fabricated } \\
\text { fenestration" used in Section 5.4.3.2, which is similar to the definition in } \\
\text { California's Title } 24 \text {. }\end{array}$ & $7 / 20 / 2010$ & $7 / 23 / 2010$ & $7 / 24 / 2010$ & $7 / 26 / 2010$ \\
\hline di & 6.4.3.4.6 & $\begin{array}{l}\text { This addendum allows for a reduction in ventilation in uncontaminated } \\
\text { garages. }\end{array}$ & $7 / 20 / 2010$ & $7 / 23 / 2010$ & $7 / 24 / 2010$ & $7 / 26 / 2010$ \\
\hline $\mathrm{dj}$ & $\begin{array}{l}\text { Table } \\
6.5 .3 .1 .1 \mathrm{~B}\end{array}$ & $\begin{array}{l}\text { This addendum provides limits on the pressure drop of energy recovery } \\
\text { devices. }\end{array}$ & $7 / 20 / 2010$ & $7 / 23 / 2010$ & $7 / 24 / 2010$ & $7 / 26 / 2010$ \\
\hline $\mathrm{dk}$ & Appendix C & $\begin{array}{l}\text { This addendum makes Standard 90.1-2010 consistent with changes made } \\
\text { in addenda al, bc, and bn. }\end{array}$ & $7 / 20 / 2010$ & $7 / 23 / 2010$ & $7 / 24 / 2010$ & $7 / 26 / 2010$ \\
\hline $\mathrm{dl}$ & Appendix C & $\begin{array}{l}\text { This addendum gives instruction to the users of Appendix } \mathrm{C} \text { on how to } \\
\text { model the base envelope design and the proposed envelope design in } \\
\text { complying with the cool roof provisions in Section } 5 \text {. }\end{array}$ & $7 / 20 / 2010$ & $7 / 23 / 2010$ & $7 / 24 / 2010$ & $7 / 26 / 2010$ \\
\hline dn & G3.1.1 & $\begin{array}{l}\text { This addendum modifies the efficiencies for variable refrigerant flow } \\
\text { equipment. }\end{array}$ & $7 / 20 / 2010$ & $7 / 23 / 2010$ & $7 / 24 / 2010$ & $7 / 26 / 2010$ \\
\hline
\end{tabular}


Table 1. (contd)

\begin{tabular}{|c|c|c|c|c|c|c|}
\hline Addendum & $\begin{array}{l}\text { Section(s) } \\
\text { Affected }\end{array}$ & Description of Changes & $\begin{array}{l}\text { ASHRAE } \\
\text { Standards } \\
\text { Committee } \\
\text { Approval }\end{array}$ & $\begin{array}{l}\text { ASHRAE } \\
\text { BOD } \\
\text { Approval }\end{array}$ & $\begin{array}{l}\text { IESNA } \\
\text { BOD } \\
\text { Approval }\end{array}$ & $\begin{array}{c}\text { ANSI } \\
\text { Approval }\end{array}$ \\
\hline do & 9.7 & $\begin{array}{l}\text { This addendum establishes the goals and requirements of the lighting } \\
\text { system including controls and to ensure that the owner is provided all } \\
\text { information necessary to best use and maintain the lighting systems. }\end{array}$ & $7 / 20 / 2010$ & $7 / 23 / 2010$ & $7 / 24 / 2010$ & $7 / 26 / 2010$ \\
\hline $\mathrm{dp}$ & Section 12 & $\begin{array}{l}\text { This addendum updates the references in Standard } 90.1 \text {. While these } \\
\text { changes reflect the current edition of the cited standard it should be } \\
\text { noted that substantive changes in the referenced documents did not affect } \\
\text { the requirements in Standard } 90.1 \text { or change the stringency of the } \\
\text { requirements of Standard } 90.1 .\end{array}$ & $7 / 20 / 2010$ & $7 / 23 / 2010$ & $7 / 24 / 2010$ & $7 / 26 / 2010$ \\
\hline $\mathrm{dq}$ & Appendix C & $\begin{array}{l}\text { This addendum modifies the calculations found in Appendix } \mathrm{C} \text { in order } \\
\text { to reflect modifications to the modeling assumptions in the equations. }\end{array}$ & 7/20/2010 & $7 / 23 / 2010$ & $7 / 24 / 2010$ & $7 / 26 / 2010$ \\
\hline $\mathrm{dr}$ & 9.4 .4 & $\begin{array}{l}\text { The original purpose for this provision was to limit the use of inefficient } \\
\text { lighting sources for high wattage applications when there was not a } \\
\text { comprehensive table of exterior Lighting Power Density (LPD) limits. } \\
\text { With the table of requirements now in the } 2007 \text { edition and beyond } \\
\text { versions of Standard 90.1, the need for this limit is superseded. }\end{array}$ & $7 / 20 / 2010$ & $7 / 23 / 2010$ & $7 / 24 / 2010$ & $7 / 26 / 2010$ \\
\hline
\end{tabular}




\subsection{Simulation Methodology}

The purpose of the final quantitative analysis described here is to provide DOE with an evaluation of the relative energy efficiency of ASHRAE Standard 90.1-2007 and ASHRAE Standard 90.1-2010 when taken as a whole. To the degree that it can be considered representative of all commercial building construction, the final analysis provides an estimate of the impact of the change in standards on commercial building energy efficiency. The quantitative comparison of energy codes was based on whole building energy simulation of buildings built to either the ASHRAE Standard 90.1-2007 or 90.12010. It is not feasible to simulate all possible permutations of building design, nor are the data available to weigh correctly each possible permutation in each possible U.S. climate as a fraction of the national building construction mix. Hence, the quantitative analysis focuses on the use of prototype buildings that reflect typical construction practices.

For the purpose of the final determination, DOE used a set of 16 commercial building prototypes based on DOE's published commercial reference building simulation models ${ }^{1}$ developed by DOE in support of the DOE Building Technologies Program Commercial Building Initiative. ${ }^{2,3}$ One additional prototype building for high-rise multifamily apartment buildings is not included in DOE's reference building models. The prototypes are implemented as building models for use with the EnergyPlus ${ }^{4}$ whole building energy simulation software. In addition, for the simulation work, each prototype building is assumed to be potentially situated in 1 of 15 climate zones, each corresponding to the 15 U.S. climate zones used in Standard 90.1-2007 and Standard 90.1-2010. For each climate zone, a most-representative location and corresponding typical meteorological year (TMY) weather file is identified, ${ }^{5}$ which results in 225 climate/prototype combinations.

The individual building models for each climate are then modified as needed to correctly reflect the prescriptive requirements for Standard 90.1-2007 as required for each climate zone. DOE received input from the ASHRAE Standard 90.1 Simulation Working Group in support of this effort, which resulted in some modifications to DOE's published commercial reference building models. In addition, for each of these Standard 90.1-2007 compliant building models, a second, corresponding building with the same basic design and use patterns, but which reflected the prescriptive requirements for Standard 90.1-2010, was developed. This latter process was completed by review of each addendum; first establishing whether that addendum would affect a given building prototype (based on the assumptions and descriptions of the benchmark building components) and in which climates.

\footnotetext{
${ }^{1}$ Also referred to in previous literature as DOE's Commercial Benchmark Building Models.

${ }^{2}$ U.S. Department of Energy-Office of Public Affairs. DOE to Pursue Zero-Net Energy Commercial Buildings: National Renewable Energy Laboratory Announces Support for Clean Tech Open. August 5, 2008. Available at http://apps1.eere.energy.gov/buildings/publications/pdfs/corporate/ns/commercial building initiative release 8 08.pdf

${ }^{3}$ U.S. Department of Energy-Office of Energy Efficiency \& Renewable Energy. Commercial Building Initiative: Commercial Building Reference Models. (Last accessed November 22, 2010.)

$<$ http://www1.eere.energy.gov/buildings/commercial_initiative/reference buildings.html>

${ }^{4}$ U.S. Department of Energy-Office of Energy Efficiency \& Renewable Energy. EnergyPlus Energy Simulation Software V4.0. Available at $<\underline{\text { http: } / / \text { apps1.eere.energy.gov/buildings }>}$

${ }^{5}$ Wilcox S and W Marion. 2008. Users Manual for TMY3 Data Sets. NREL/TP-581-43156, Revised May 2008, National Renewable Energy Laboratory, Golden, Colorado.. Available at $<\underline{w w w . n r e l . g o v / d o c s / f y 080 s t i / 43156 . p d f ~}>$
} 
Each of the 480 resulting building models was then simulated using EnergyPlus, and the resulting energy use was extracted by fuel type and by end use. The energy-use data were then aggregated by fuel type and, using the floor space for each prototype, were converted to EUI metrics for each fuel by building prototype by climate and standard level.

DOE developed estimates of the new construction floor space that correspond to each prototype/climate zone combination. It then used these data to develop the relative fraction of new construction floor space represented by building prototype and within the 15 climate zones. Using the EUI statistics from each building simulation and the corresponding relative fraction of new construction floor space, DOE developed floor-space-weighted national EUI statistics by fuel type for each building type and standard level. DOE then added these fuel-specific EUI estimates to obtain the national site energy EUI by building type and standard level. DOE also applied national data for average fuel prices data and average primary energy fuel conversion rates to the fuel-specific EUI data to obtain estimates of national primary energy EUI and national energy cost intensity (ECI), again by building type and by Standard 90.1 level. DOE examined the national results by building prototype to determine which building types would show a reduction in energy use under Standard 90.1-2010.

Finally, DOE used the relative floor space data for each of the building types nationally to weight the EUI and ECI statistics by building type to arrive at national site EUI, primary energy EUI, and ECI values for buildings constructed under both editions of Standard 90.1. The approach taken is not comprehensive for all buildings. The analysis assesses the relative energy impact of the standard by simulation of prototypical examples of buildings of various types reflected in the overall building population. It is recognized that there will be specific requirements of the standard that will not be amenable to simulation within the scope of this analysis. For most of these specific requirements, any differences in requirements will suggest an obvious stringency change between the standards, and this has been explored in the qualitative analysis done in parallel to this quantitative assessment.

\subsection{Building Types and Model Prototypes}

Sixteen DOE prototype buildings (Table 2) were used in the DOE final quantitative analysis. A seventeenth DOE prototype, or reference building model supermarket, was not used for the final quantitative analysis because an extant benchmark was not available at the start of the final determination process. Each DOE reference building model building is defined as characteristic of a certain class of buildings, mostly corresponding to a classification scheme established in the $2003 \mathrm{DOE} /$ Energy Information Administration (EIA) Commercial Building Energy Consumption Survey (CBECS). ${ }^{1}$ CBECS categorizes commercial buildings using variables principal building activity (PBA) and PBAplus for more specific activities, separating the commercial sector into 29 PBA categories and 51 further subcategories. DOE relied heavily on these classifications in determining the buildings to be represented by the set of reference building models. By mapping CBECS observations to each prototype, DOE also used the CBECS building characteristics data to develop reference buildings that could best typify the building stock represented by each. Multi-family housing buildings are not included in CBECS but are covered by Standard 90.1 if more than three stories high. Consequently, DOE developed a mid-rise

\footnotetext{
${ }^{1}$ U.S. Energy Information Administration. 2003 Commercial Buildings Energy Consumption Survey-Overview of Commercial Buildings Characteristics. (Last accessed March 31, 2010.)

$<\underline{\text { http://www.eia.doe.gov/emeu/cbecs/cbecs2003/introduction.html }>}$
} 
apartment building to add to the original reference building prototypes identified through the review of CBECS. The characteristics of the mid-rise and high-rise multifamily buildings were developed from data in a separate study by PNNL. ${ }^{1}$

Table 2. ASHRAE Commercial Reference Building Models

\begin{tabular}{|c|c|c|}
\hline Building Type & Building Prototype & $\begin{array}{c}\text { Prototype } \\
\text { Floor Area } \\
\left(\mathrm{ft}^{2}\right)\end{array}$ \\
\hline \multirow[t]{3}{*}{ Office } & Small Office & 5,502 \\
\hline & Medium Office & 53,628 \\
\hline & Large Office & 498,588 \\
\hline \multirow[t]{2}{*}{ Retail } & Stand-Alone Retail & 24,692 \\
\hline & Strip Mall & 22,500 \\
\hline \multirow[t]{2}{*}{ Education } & Primary School & 73,959 \\
\hline & Secondary School & 210,887 \\
\hline \multirow[t]{2}{*}{ Healthcare } & Outpatient Health Care & 40,946 \\
\hline & Hospital & 241,501 \\
\hline \multirow[t]{2}{*}{ Lodging } & Small Hotel & 43,202 \\
\hline & Large Hotel & 122,120 \\
\hline Warehouse & Non-Refrigerated Warehouse & 52,045 \\
\hline \multirow[t]{2}{*}{ Food Service } & Fast Food Restaurant & 2,501 \\
\hline & Sit-Down Restaurant & 5,502 \\
\hline \multirow[t]{2}{*}{ Apartment } & Mid-Rise Apartment & 33,741 \\
\hline & High-Rise Apartment & 84,360 \\
\hline
\end{tabular}

In the case of office buildings, one of the largest PBA categories in terms of square footage of stock, DOE determined that the wide variation in building design and equipment use made determining a "typical" office design difficult. Consequently, DOE developed three sizes and form factors characteristic of small, medium, and large office buildings to reflect the wide variation of office building design.

To keep the building set manageable, the basic form factor and equipment selection for each reference building was developed to be most typical of construction on a national basis. It is thus characteristic of a specific construction. Regional variation in form factor, size, or design differences such as equipment selection are not represented in the group of reference buildings.

As stated previously, the original basis of the building models used in the final quantitative analysis is the new construction set of reference building models posted by DOE that are believed to represent the typical new building architectural program and design, and use ASHRAE Standard 90.1-2004 as the basis for many construction specifics. Each of these DOE benchmark buildings was subsequently vetted through the ASHRAE Standard 90.1 subcommittee to clarify further construction and operation assumptions by building type and to confirm that the building models accurately reflect the requirements of ASHRAE Standard 90.1-2004. Because this review process resulted in some modification of assumptions from the original DOE reference building models, this revised second set of 16 prototypes

\footnotetext{
${ }^{1}$ Gowri K, MA Halverson, and EE Richman. 2007. Analysis of Energy Saving Impacts of ASHRAE 90.1-2004 for New York. PNNL-16770, Pacific Northwest National Laboratory, Richland, Washington..
} 
actually used in the final quantitative analysis is referred to as the ASHRAE reference buildings (or the prototypes). ASHRAE's Standard 90.1 Standing Standards Project Committee (SSPC) is working with DOE to use this set of ASHRAE reference buildings to establish the energy benefits of ongoing addenda being considered for subsequent editions of Standard 90.1. DOE has posted both ASHRAE 90.1-2007and ASHRAE 90.1-2010-compliant versions of these 16 reference buildings on the DOE website as background information for DOE's final determination at http://www.energycodes.gov/implement/determinations_90.1-2007.stm. The 90.1 SSPC reviews have already resulted in changes to some of the original DOE-developed reference buildings, and it is anticipated that further updates will result in a single set of reference building models.

The 16 categories of building types used in the final quantitative analysis together reflect approximately 80 percent of the total square footage of commercial construction, including multifamily buildings more than three stories tall, covered under ASHRAE Standard 90.1.

\subsection{Inclusion of Addenda}

In the final qualitative analysis, DOE identified 34 specific addenda that would have a measurable impact using the simulation methodology and that would be modeled in the final quantitative analysis. DOE examined each of the 109 addenda to Standard 90.1-2007 and specifically identified which of the ASHRAE reference building models would be affected by the addenda and modified to reflect inclusion of the addenda for the final quantitative analysis. Where an addendum was believed to have no readily discernable energy impact, this was also identified. For certain addenda, DOE determined that while the addendum might have an impact on commercial building energy use, the analysis methodology could not readily capture that impact, usually because the energy using building feature affected was not represented in any of the reference building models.

In addition, an underlying theme in the final quantitative analysis was that the analysis reflects real changes to building code requirements that would be expected to be either required by States, or whose impact on energy use would be reflected in revised State building codes (because EPCA requirements for State building codes do not explicitly require adoption of Standard 90.1 or specific addenda, rather the overall updated building code efficiency must be equivalent to that of the latest edition of Standard 90.1 for which DOE issued a positive determination). This theme results in special treatment of addenda in two key areas: ventilation requirements and equipment efficiency changes.

\subsection{Ventilation}

The final quantitative analysis assumed the same base ventilation level for buildings constructed to Standard 90.1-2007 and Standard 90.1-2010. Neither edition of Standard 90.1 specifies minimum or maximum ventilation rates for commercial building construction. ASHRAE has a separate ventilation standard for commercial construction, ANSI/ASHRAE Standard 62.1, "Ventilation for Acceptable Indoor Air Quality." This ventilation standard is cited only in a few specific requirement exceptions within the mechanical sections of either ASHRAE Standard 90.1-2007 or ASHRAE Standard 90.1-2010, with each edition referencing a different edition of Standard 62.1. ASHRAE Standard 90.1-2007 lists 
ASHRAE Standard 62.1-2004 in its table of references; ASHRAE Standard 90.1-2010 lists ASHRAE Standard 62.1-2007 in its table of references. The most recent edition of ASHRAE Standard 62.1 is now Standard 62.1-2007. ${ }^{1}$

Ventilation rates can have a significant impact on the energy use of commercial buildings. States and local jurisdictions typically specify the ventilation requirements for buildings within their respective building codes and set these requirements independent of the energy code requirements. Because of the limited and oblique references to ventilation requirements (through exceptions to actual requirements) within either edition of ASHRAE Standard 90.1, the requirements that States certify that their energy codes meet or exceed the latest edition of ASHRAE Standard 90.1 will in general not require modification of State ventilation code requirements. DOE recognizes that in many cases, State ventilation requirements can be traced back to requirements found in one or another edition of ASHRAE Standard 62.1. For the quantitative analysis, DOE assumed the ventilation rate for the simulation prototypes based on the requirements of ASHRAE Standard 62.1-2004.

\subsection{Equipment Efficiency and Mandatory Federal Efficiency Standards}

Both Standard 90.1-2007 and Standard 90.1-2010 contain specific tables of HVAC and service water heating equipment efficiency requirements. Most, but not all, of the equipment classes shown in these Standard 90.1 tables have minimum Federal efficiency standards applied to them. The overlap between Federal efficiency standards and the requirements shown in ASHRAE Standard 90.1 as a model code result in specific complications for an analysis used to inform a DOE determination of energy savings. In some instances, a revised edition of Standard 90.1 will adopt an existing Federal efficiency standard into its tabulated efficiency requirement, typically with the same effective date as provided by the Federal standard. Because that mandated equipment efficiency will be enforced as a manufacturing standard regardless of whether it is represented in Standard 90.1, the inclusion of the requirement in the ASHRAE standard has no real energy impact. DOE's quantitative analysis methodology includes any equipment efficiency improvements mandated by Federal equipment efficiency standards, either established by DOE or by legislation, but not initiated by addenda to ASHRAE Standard 90.1-2007 in the ASHRAE Standard 90.1-2007 baseline. This prevents inclusion in the quantitative analysis energy savings that would occur in new building construction (due to these mandated equipment efficiency improvements) regardless of the use of Standard 90.1-2007 or Standard 90.1-2010 as the basis for State building codes, and it prevents an incorrect biasing of the quantitative analysis toward positive energy savings from federally mandated equipment efficiency improvements. Not including credit for these addenda in the quantitative analysis is consistent with the approach used in previous DOE determinations.

Historically, Standard 90.1 has provided for improved efficiency in mechanical equipment with primarily commercial applications, using effective dates that occur after the standard is published, typically 2 or 3 years after publication. It has done so primarily to give manufacturers time to make available higher-efficiency equipment on the market for those States adopting the revised Standard 90.1 efficiency levels. For most of this commercial HVAC and service water heating equipment, revisions to

\footnotetext{
${ }^{1}$ American Society of Heating, Refrigerating and Air-Conditioning Engineers, Inc. 2002. ASHRAE Standard: Ventilation for Acceptable Indoor Air Quality. ANSI/ASHRAE Addendum 62o to ANSI/ASHRAE Standard 622001, Atlanta, Georgia. Available at $<\underline{\text { http://www.ashrae.org/content/ASHRAE/ASHRAE/ArticleAltFormat/200377135714 347.pdf }>>}$
} 
ASHRAE also serve as a trigger for DOE to revise minimum manufacturing efficiency standards for this equipment. Revised minimum manufacturing standards set by DOE for this equipment are generally subject to a provision that they be no less efficient than those shown in the most recent edition of ASHRAE Standard 90.1; however, manufacturing standards generally will not be in effect for between 2 to 4 years after they are in effect in the ASHRAE standard (42 U.S.C. 6291 et seq., as amended; EPCA). For this reason, the publication of commercial equipment efficiency improvements in a revised Standard 90.1 results in improved efficiency in commercial buildings, particularly for States and jurisdictions that adopt Standard 90.1 efficiency requirements prior to these requirements being adopted as Federal manufacturing standards. In addition, because it serves as a trigger for a broader DOE rulemaking on Federal manufacturing standards, the publication in Standard 90.1 will eventually have an impact on efficiency of commercial buildings in all U.S. jurisdictions. However, a concern related to the final determination is how to treat an addendum to Standard 90.1 that results in an increase in commercial equipment efficiency in the far future. In the case of Standards 90.1-2007 and 90.1-2010, ASHRAE set the effective date of certain of these revised efficiency levels as far out as 2020, 13 years from the original publication date of Standard 90.1-2007. Because Standard 90.1 is currently revised on a 3-year cycle, DOE preliminarily determined that it would only include the effect of equipment efficiency changes in the Standard 90.1-2007 whose effective date in Standard 90.1 is within 3 years of the date of the publication of the revised standard. Efficiency improvements with effective dates more than 3 years after publication will be considered in DOE's determinations about forthcoming editions of Standard 90.1.

Table 3 identifies each of the 34 Standard 90.1-2007 addenda that save energy and can be modeled in the reference buildings. Addenda judged to have no significant impact on the quantitative analysis are not included in Table 3.

Table 3. Addenda Included in Quantitative Analysis

\begin{tabular}{|c|c|c|}
\hline Addendum & $\begin{array}{l}\text { Sections } \\
\text { Affected }\end{array}$ & Description \\
\hline $\mathrm{d}$ & $5.5 .4 .4,9.7$ & $\begin{array}{l}\text { This addendum modifies the daylighting requirements to allow the use of } \\
\text { photocontrols combined with skylighting to reduce the electricity used for lighting. }\end{array}$ \\
\hline e & 6.5.6 & $\begin{array}{l}\text { This addendum modifies the requirements for energy recovery by expanding them } \\
\text { to cover the use of energy recovery by weather zone. }\end{array}$ \\
\hline $\mathrm{f}$ & 5.5.3.1 & This addendum sets requirements for high-albedo roofs. \\
\hline $\mathrm{g}$ & $\begin{array}{l}\text { Section 5, } \\
\text { Normative } \\
\text { Appendix A2.3 }\end{array}$ & This addendum updates the building envelope criteria for metal buildings. \\
\hline $\mathrm{h}$ & 6.5.2.1 & $\begin{array}{l}\text { This addendum adds a new exception that is geared toward zones with direct digital } \\
\text { controls (DDC). }\end{array}$ \\
\hline $\mathrm{i}$ & 9.4 .5 & $\begin{array}{l}\text { This addendum applies a four-zone lighting power density (LPD) approach to } \\
\text { exterior lighting requirements. }\end{array}$ \\
\hline $\mathrm{m}$ & $\begin{array}{l}\text { Section 6.4.1.2, } \\
\text { Table 6.8.1C }\end{array}$ & $\begin{array}{l}\text { This addendum establishes effective January } 1,2010 \text {, an additional path of } \\
\text { compliance for water-cooled chillers and also combines all water-cooled positive } \\
\text { displacement chillers into one category and adds a new size category for } \\
\text { centrifugal chillers at or above } 600 \text { tons. }\end{array}$ \\
\hline $\mathrm{n}$ & 6.4.3.10 & $\begin{array}{l}\text { This addendum extends variable air volume fan control requirements to large } \\
\text { single-zone units. }\end{array}$ \\
\hline
\end{tabular}


Table 3. (contd)

\begin{tabular}{|c|c|c|}
\hline Addendum & $\begin{array}{l}\text { Sections } \\
\text { Affected }\end{array}$ & Description \\
\hline $\mathrm{q}$ & 5.4 .3 .4 & This addendum modifies the vestibule requirements for climate zone 4 . \\
\hline $\mathrm{u}$ & 6.5.5.3 & This addendum adds requirements for axial fan open-circuit cooling towers. \\
\hline $\mathrm{x}$ & 9.4.1.1 & $\begin{array}{l}\text { This revision updates the requirements for automatic lighting shutoffs, adds specific } \\
\text { occupancy sensor applications, and provides additional clarification. }\end{array}$ \\
\hline aa & 9.4 .1 & This change mandates that lighting controls have a "manual on" capability. \\
\hline$a b$ & 9.4 .1 & $\begin{array}{l}\text { This change modifies skylighting and daylighting requirements from addendum d } \\
\text { to Standard 90.1-2007. }\end{array}$ \\
\hline af & 6.5.4.5 & Prescribes maximum flow rates through chilled water and condenser water piping. \\
\hline ak & 6.5 .4 & $\begin{array}{l}\text { Modifies requirements for Heat Pump and Water-Cooled Unitary Air-Conditioners, } \\
\text { Differential Pressure Reset, fan power limitations, chilled water cooling, and } \\
\text { deletion of } 10 \mathrm{hp} \text { from Section 6.5.4 }\end{array}$ \\
\hline al & 5.5.4.2.3 & $\begin{array}{l}\text { Adds skylight requirements in certain space types to promote daylighting energy } \\
\text { savings. }\end{array}$ \\
\hline am & 5.4.3.2 & Revises air-leakage criteria so they more closely reflect current practice. \\
\hline ap & 6.3 .2 & Modifies the requirements for demand control ventilation (DCV). \\
\hline as & 6.5.2.1 & $\begin{array}{l}\text { Removes exception for variable air volume (VAV) turndown requirements for } \\
\text { zones with special pressurization requirements. Reduces laboratory threshold } \\
\text { where VAV or heat recovery is required. }\end{array}$ \\
\hline aw & 9.4.1.4 & $\begin{array}{l}\text { Recognizes the practical design application of excluding bathroom lighting from } \\
\text { "master" switch control in hotel/motel guest rooms and adds a requirement to } \\
\text { eliminate wasted light in guest room bathrooms. }\end{array}$ \\
\hline ax & 6.5.7.1 & Modifies requirements for kitchen exhaust. \\
\hline bf & 5.4.3.1 & Provides performance requirements for air leakage of the opaque envelope. \\
\hline bh & 6.5.3.3 & $\begin{array}{l}\text { Provides requirements for multiple-zone HVAC systems (that include simultaneous } \\
\text { heating and cooling) to include controls that automatically raise the supply-air } \\
\text { temperature when the spaces served are not at peak load conditions. }\end{array}$ \\
\hline bn & 5.5.4.5 & $\begin{array}{l}\text { Limits poorly oriented fenestration. Compliance can be shown by having more } \\
\text { south-facing fenestration than west facing fenestration. For those buildings } \\
\text { affected by this requirement, this reduces envelope loads, energy usage and thereby } \\
\text { costs. }\end{array}$ \\
\hline $\mathrm{bq}$ & 9.6 .2 & $\begin{array}{l}\text { Changes the requirements for retail space lighting, which will make use of more } \\
\text { recent lamp technology that is readily available. }\end{array}$ \\
\hline bs & 8.4 .2 & $\begin{array}{l}\text { This new requirement will provide the means for non-critical receptacle loads to be } \\
\text { automatically controlled (turned off) based on occupancy or scheduling without } \\
\text { additional individual desk top or similar controllers. }\end{array}$ \\
\hline by & $\begin{array}{l}\text { 9.6.2, } \\
\text { Table } 9.5 .1\end{array}$ & $\begin{array}{l}\text { Proposes new LPDs for both the whole building and space-by-space compliance } \\
\text { methods. In addition, the Lighting Power Density may be re-calculated based on } \\
\text { room geometry. }\end{array}$ \\
\hline $\mathrm{ca}$ & 6.5.3.1.1 & $\begin{array}{l}\text { Closes a loophole in the fan power allowances for single-zone VAV systems. } \\
\text { Standard VAV systems are multi-zone systems with terminal units containing } \\
\text { control dampers to vary airflow to individual zone. }\end{array}$ \\
\hline $\mathrm{cb}$ & $6.3 .2,6.4 .3 .4 .2$ & $\begin{array}{l}\text { This addendum includes a number of changes to require simple systems to meet } \\
\text { prescriptive outdoor air damper requirements, allow backdraft dampers only for } \\
\text { exhaust and relief dampers in buildings less than three stories in height, require } \\
\text { backdraft dampers on outdoor air intakes to be protected from wind, and limit } \\
\text { windblown infiltration through the damper. }\end{array}$ \\
\hline
\end{tabular}


Table 3. (contd)

\begin{tabular}{|c|c|c|}
\hline Addendum & $\begin{array}{l}\text { Sections } \\
\text { Affected }\end{array}$ & Description \\
\hline $\mathrm{cc}$ & Table 6.5.4.5 & $\begin{array}{l}\text { This addendum fixes a mistake in the way } 8 \text {-in. pipe was analyzed. RS Means data } \\
\text { for threaded pipe was used for } 8 \text {-in.when welded pipe data should have been used. } \\
\text { It also includes a minor editorial change because it is not possible to operate more } \\
\text { than } 8,760 \mathrm{~h} / \mathrm{yr} \text {. }\end{array}$ \\
\hline ck & 6.5 .3 & $\begin{array}{l}\text { This addendum expands zone-level demand-controlled ventilation to include } \\
\text { various forms of system-level strategies. }\end{array}$ \\
\hline cs & 8.4 .2 & $\begin{array}{l}\text { Modifies automatic receptacle control requirements and exemptions to eliminate } \\
\text { potential practical application issues. }\end{array}$ \\
\hline cy & 6.5 .1 & $\begin{array}{l}\text { This addendum makes several revisions to the economizer requirements in } \\
\text { Section } 6.5 .1 \text { and in Section 6.3.2. With increased envelope insulation levels and } \\
\text { higher internal plug loads we are seeing commercial buildings operating in cooling } \\
\text { at lower ambient temperatures. This allows for greater air and water economizers } \\
\text { to be used instead of mechanical cooling. }\end{array}$ \\
\hline de & Table 9.6.1 & $\begin{array}{l}\text { This addendum lowers the LPDs in some lobbies in Standard } 90.1 \text { to reflect } \\
\text { advances in lighting technology. }\end{array}$ \\
\hline
\end{tabular}

\subsection{Modeling of Specific Addenda}

Details of the modeling of specific addenda to Standard 90.1-2007 are available in the technical support document for DOE's progress indicator to ASHRAE on Standard 90.1-2010. The detailed model descriptions are presented in the PNNL report entitled "Achieving 30\% Goal: Energy and Cost Saving Analysis of ASHRAE/IES Standard 90.1-2010"1.

\subsection{Simulation of Prototypes and Extraction of Results}

Simulation of all 480 prototype/climate zones combinations was done using EnergyPlus. Each prototype is first simulated using a set of design-day runs based on ASHRAE design-day conditions. Certain specific data related to sizing of systems and equipment and necessary for determining the impact of addenda are extracted from the design-day runs. Necessary updates to the input decks for each prototype type are made to correctly reflect the addenda, and an annual run is then performed for each of the prototypes in each climate and at each standard level. Annual energy use for each annual simulation by fuel type (natural gas or electricity) is extracted for each simulation both by end use and at the whole building level. Data for each building prototype in each climate zone are extracted from the EnergyPlus simulations results using PERL scripting tools and the data are incorporated into special purpose spreadsheets to weight to nationwide results. The energy use data are converted to EUI data by dividing by the building area for each prototype. This EUI data are then weighted using weighting factors discussed in the next section to provide nationally representative results.

\footnotetext{
${ }^{1}$ Available at http://www.energycodes.gov/publications/research/documents/codes/PNNL-20405.pdf.
} 


\subsection{Development of Weighting Factors}

For this weighting, weighting factors were developed based on 5 years of construction data purchased by DOE from McGraw Hill's FW DODGE data set. Development of the weighting factors is discussed in a DOE/PNNL report, ${ }^{1}$ which details weighting factors for 16 building prototypes, including the highrise apartment commercial reference building prototype. Table 4 lists the resulting weighting factors by climate and by building prototype used for each prototype in the final determination.

\footnotetext{
${ }^{1}$ Jarnagin RE and GK Bandyopadhyay. 2010. Weighting Factors for the Commercial Building Prototypes Used in the Development of ANSI/ASHRAE/IENSA Standard 90.1-2010. PNNL-19116, Pacific Northwest National Laboratory, Richland, Washington.
} 
Table 4. Relative Construction Volume Weights for 16 ASHRAE Building Prototypes by Climate Zone

\begin{tabular}{|c|c|c|c|c|c|c|c|c|c|c|c|c|c|c|c|c|}
\hline Building Type & 1 & $2 \mathrm{~A}$ & $2 \mathrm{~B}$ & $3 \mathrm{~A}$ & $3 \mathrm{~B}$ & $3 \mathrm{C}$ & $4 \mathrm{~A}$ & $4 \mathrm{~B}$ & $4 \mathrm{C}$ & $5 \mathrm{~A}$ & $5 \mathrm{~B}$ & $6 \mathrm{~A}$ & $6 \mathrm{~B}$ & 7 & 8 & $\begin{array}{c}\text { Weights } \\
\text { by Bldg } \\
\text { Type }\end{array}$ \\
\hline Large office & 0.102 & 0.326 & 0.061 & 0.445 & 0.285 & 0.117 & 1.132 & 0.000 & 0.154 & 0.442 & 0.121 & 0.133 & 0.000 & 0.011 & 0.000 & 3.33 \\
\hline Medium office & 0.129 & 0.813 & 0.292 & 0.766 & 0.715 & 0.136 & 1.190 & 0.036 & 0.196 & 1.060 & 0.342 & 0.298 & 0.035 & 0.033 & 0.007 & 6.05 \\
\hline Small office & 0.084 & 1.064 & 0.289 & 0.963 & 0.475 & 0.078 & 0.936 & 0.047 & 0.123 & 0.920 & 0.322 & 0.241 & 0.030 & 0.032 & 0.005 & 5.61 \\
\hline Standalone retail & 0.224 & 2.220 & 0.507 & 2.386 & 1.250 & 0.191 & 2.545 & 0.119 & 0.428 & 3.429 & 0.792 & 0.948 & 0.091 & 0.109 & 0.014 & 15.25 \\
\hline Strip mall retail & 0.137 & 0.991 & 0.254 & 1.021 & 0.626 & 0.103 & 1.008 & 0.023 & 0.107 & 1.023 & 0.201 & 0.153 & 0.016 & 0.007 & 0.001 & 5.67 \\
\hline Primary school & 0.064 & 0.933 & 0.164 & 0.944 & 0.446 & 0.048 & 0.895 & 0.030 & 0.094 & 0.920 & 0.224 & 0.168 & 0.037 & 0.023 & 0.003 & 4.99 \\
\hline Secondary school & 0.160 & 1.523 & 0.230 & 1.893 & 0.819 & 0.109 & 2.013 & 0.063 & 0.243 & 2.282 & 0.438 & 0.415 & 0.086 & 0.075 & 0.012 & 10.36 \\
\hline Hospital & 0.040 & 0.479 & 0.096 & 0.468 & 0.273 & 0.039 & 0.615 & 0.022 & 0.106 & 0.812 & 0.218 & 0.221 & 0.024 & 0.034 & 0.001 & 3.45 \\
\hline $\begin{array}{l}\text { Outpatient } \\
\text { health care }\end{array}$ & 0.037 & 0.567 & 0.134 & 0.581 & 0.275 & 0.061 & 0.818 & 0.023 & 0.181 & 1.058 & 0.218 & 0.342 & 0.033 & 0.039 & 0.002 & 4.37 \\
\hline $\begin{array}{l}\text { Full-service } \\
\text { restaurant }\end{array}$ & 0.009 & 0.106 & 0.025 & 0.111 & 0.047 & 0.006 & 0.127 & 0.006 & 0.010 & 0.143 & 0.031 & 0.031 & 0.004 & 0.004 & 0.000 & 0.66 \\
\hline $\begin{array}{l}\text { Quick-service } \\
\text { restaurant }\end{array}$ & 0.008 & 0.092 & 0.020 & 0.102 & 0.063 & 0.007 & 0.089 & 0.005 & 0.014 & 0.128 & 0.026 & 0.025 & 0.003 & 0.004 & 0.000 & 0.59 \\
\hline Large hotel & 0.109 & 0.621 & 0.125 & 0.635 & 0.793 & 0.106 & 0.958 & 0.037 & 0.123 & 0.919 & 0.200 & 0.227 & 0.058 & 0.038 & 0.004 & 4.95 \\
\hline Small hotel & 0.010 & 0.288 & 0.030 & 0.268 & 0.114 & 0.022 & 0.315 & 0.020 & 0.039 & 0.365 & 0.089 & 0.107 & 0.031 & 0.020 & 0.004 & 1.72 \\
\hline Warehouse & 0.349 & 2.590 & 0.580 & 2.966 & 2.298 & 0.154 & 2.446 & 0.068 & 0.435 & 3.580 & 0.688 & 0.466 & 0.049 & 0.043 & 0.002 & 16.72 \\
\hline High-rise apartment & 1.521 & 1.512 & 0.076 & 0.652 & 0.741 & 0.173 & 2.506 & 0.000 & 0.358 & 1.163 & 0.115 & 0.125 & 0.016 & 0.008 & 0.000 & 8.97 \\
\hline Mid-rise apartment & 0.257 & 1.094 & 0.093 & 0.825 & 0.862 & 0.260 & 1.694 & 0.022 & 0.371 & 1.122 & 0.318 & 0.313 & 0.056 & 0.032 & 0.000 & 7.32 \\
\hline Weights by Zone & 3.24 & 15.22 & 2.98 & 15.03 & 10.08 & 1.61 & 19.29 & 0.52 & 2.98 & 19.37 & 4.34 & 4.21 & 0.57 & 0.51 & 0.06 & 100.00 \\
\hline
\end{tabular}




\subsection{Results}

Table 5 and Table 6 list the national EUI by building type for the 16 building prototypes analyzed and on an aggregated national basis for the 2007 and 2010 editions, respectively, based on the weighting factors discussed previously. For each edition of Standard 90.1, the national building floor area weight used to calculate the national impact on building EUI or building ECI is presented. The national average electricity and gas building EUI is presented separately for each building prototype analyzed, electricity being the predominant energy usage in all prototypes.

DOE's prototypes reflect the use of two fuel types, electricity and natural gas. Using the weighting factors, DOE was able to establish an estimate of the relative reduction in building energy use, as determined by a calculated reduction in weighted average site EUI for each building prototype. Site energy refers to the energy consumed at the building site. In a corresponding fashion, DOE was also able to calculate a reduction in terms of weighted average primary EUI and in terms of weighted average ECI in dollars per square foot of building floor space. Primary energy, as used here, refers to the energy required to generate and deliver energy to the site. To estimate primary energy, all electrical EUIs were first converted to primary energy using a factor of 10,918 Btu of primary energy per kilowatt-hour (based on the 2010 estimated values reported in Table 2 of the EIA 2010 Annual Energy Outlook [AEO], release date December 2009, available at http://www.eia.doe.gov/oiaf/archive/aeo10/aeoref tab.html).

Table 5. Estimated Energy Use Intensity by Building Type - 2007 Edition

\begin{tabular}{|c|c|c|c|c|c|}
\hline \multirow[b]{2}{*}{$\begin{array}{c}\text { Building } \\
\text { Type }\end{array}$} & \multirow[b]{2}{*}{ Building Prototype } & \multirow{2}{*}{$\begin{array}{c}\text { Building } \\
\text { Type Floor } \\
\text { Area Weight } \\
\% \\
\end{array}$} & \multicolumn{3}{|c|}{ Whole Building EUI Data for Building Population } \\
\hline & & & $\begin{array}{c}\text { Site EUI } \\
\mathrm{kBtu} / \mathrm{ft}^{2}-\mathrm{yr}\end{array}$ & $\begin{array}{c}\text { Source EUI } \\
\mathrm{kBtu} / \mathrm{ft}^{2}-\mathrm{yr}\end{array}$ & $\begin{array}{c}\text { ECI } \\
\$ / \mathrm{ft}^{2}-\mathrm{yr}\end{array}$ \\
\hline \multirow[t]{3}{*}{ Office } & Small Office & 5.61 & 39.1 & 118.4 & $\$ 1.11$ \\
\hline & Medium Office & 6.05 & 47.7 & 140.6 & $\$ 1.32$ \\
\hline & Large Office & 3.33 & 42.8 & 123.3 & $\$ 1.16$ \\
\hline \multirow[t]{2}{*}{ Retail } & Stand-Alone Retail & 15.25 & 65.0 & 179.5 & $\$ 1.69$ \\
\hline & Strip Mall & 5.67 & 68.3 & 186.0 & $\$ 1.75$ \\
\hline \multirow[t]{2}{*}{ Education } & Primary School & 4.99 & 63.4 & 170.2 & $\$ 1.60$ \\
\hline & Secondary School & 10.36 & 54.2 & 149.7 & $\$ 1.41$ \\
\hline \multirow[t]{2}{*}{ Healthcare } & Outpatient Health Care & 4.37 & 162.0 & 438.0 & $\$ 4.11$ \\
\hline & Hospital & 3.45 & 156.4 & 374.9 & $\$ 3.51$ \\
\hline \multirow[t]{2}{*}{ Lodging } & Small Hotel & 1.72 & 70.8 & 179.4 & $\$ 1.68$ \\
\hline & Large Hotel & 4.95 & 157.1 & 315.8 & $\$ 2.95$ \\
\hline Warehouse & Non-Refrigerated Warehouse & 16.72 & 24.2 & 58.6 & $\$ 0.55$ \\
\hline \multirow{2}{*}{$\begin{array}{l}\text { Food } \\
\text { Service }\end{array}$} & Fast-Food Restaurant & 0.59 & 547.7 & 1068.0 & $\$ 9.98$ \\
\hline & Sit-Down Restaurant & 0.66 & 382.4 & 810.7 & $\$ 7.59$ \\
\hline \multirow[t]{2}{*}{ Apartment } & Mid-Rise Apartment & 7.32 & 44.2 & 123.7 & $\$ 1.16$ \\
\hline & High-Rise Apartment & 8.97 & 44.2 & 129.3 & $\$ 1.22$ \\
\hline National & & 100 & 67.5 & 174.0 & $\$ 1.63$ \\
\hline
\end{tabular}


Table 6. Estimated Energy Use Intensity by Building Type - 2010 Edition

\begin{tabular}{|c|c|c|c|c|c|}
\hline \multirow[b]{2}{*}{$\begin{array}{l}\text { Building } \\
\text { Type }\end{array}$} & \multirow[b]{2}{*}{ Building Prototype } & \multirow{2}{*}{$\begin{array}{c}\text { Building } \\
\text { Type Floor } \\
\text { Area Weight } \\
\%\end{array}$} & \multicolumn{3}{|c|}{ Whole Building EUI Data for Building Population } \\
\hline & & & $\begin{array}{c}\text { Site EUI } \\
\mathrm{kBtu} / \mathrm{ft}^{2}-\mathrm{yr}\end{array}$ & $\begin{array}{l}\text { Source EUI } \\
\mathrm{kBtu} / \mathrm{ft}^{2}-\mathrm{yr}\end{array}$ & $\begin{array}{c}\text { ECI } \\
\$ / \mathrm{ft}^{2}-\mathrm{yr}\end{array}$ \\
\hline \multirow[t]{3}{*}{ Office } & Small Office & 5.61 & 32.8 & 99.0 & $\$ 0.93$ \\
\hline & Medium Office & 6.05 & 37.1 & 106.3 & $\$ 1.00$ \\
\hline & Large Office & 3.33 & 33.3 & 96.8 & $\$ 0.91$ \\
\hline \multirow[t]{2}{*}{ Retail } & Stand-Alone Retail & 15.25 & 48.0 & 135.1 & $\$ 1.27$ \\
\hline & Strip Mall & 5.67 & 56.9 & 150.9 & $\$ 1.42$ \\
\hline \multirow[t]{2}{*}{ Education } & Primary School & 4.99 & 48.0 & 134.8 & $\$ 1.27$ \\
\hline & Secondary School & 10.36 & 39.8 & 114.9 & $\$ 1.08$ \\
\hline \multirow[t]{2}{*}{ Healthcare } & Outpatient Health Care & 4.37 & 125.4 & 340.9 & $\$ 3.20$ \\
\hline & Hospital & 3.45 & 118.1 & 299.5 & $\$ 2.81$ \\
\hline \multirow[t]{2}{*}{ Lodging } & Small Hotel & 1.72 & 66.6 & 165.7 & $\$ 1.55$ \\
\hline & Large Hotel & 4.95 & 139.8 & 282.5 & $\$ 2.64$ \\
\hline Warehouse & $\begin{array}{l}\text { Non-Refrigerated } \\
\text { Warehouse }\end{array}$ & 16.72 & 19.2 & 45.0 & $\$ 0.42$ \\
\hline \multirow[t]{2}{*}{ Food Service } & Fast-Food Restaurant & 0.59 & 519.9 & 976.5 & $\$ 9.12$ \\
\hline & Sit-Down Restaurant & 0.66 & 330.9 & 654.1 & $\$ 6.12$ \\
\hline \multirow[t]{2}{*}{ Apartment } & Mid-Rise Apartment & 7.32 & 41.2 & 118.3 & $\$ 1.11$ \\
\hline & High-Rise Apartment & 8.97 & 41.0 & 123.5 & $\$ 1.16$ \\
\hline National & & 100 & 55.0 & 142.4 & $\$ 1.34$ \\
\hline
\end{tabular}

The conversion factor of 10,918 was calculated from AEO Table 2 by summing the commercial electricity value of 4.62 quads with the electricity losses value of 10.17 quads and then dividing that sum by the commercial value $((4.62+10.17) / 4.62=3.2)$. This yields an electricity ratio of 3.2 for converting how much primary (source) electricity is required per unit of site required electricity. This ratio of 3.2 is then multiplied by $3,412 \mathrm{Btu} / \mathrm{kWh}$, producing a value of $10,918 \mathrm{Btu}$ of primary energy per kilowatt-hour of site energy. Natural gas EUIs in the prototypes were converted to primary energy using a factor of 1.090 Btu of primary energy per Btu of site natural gas use (based on the 2010 national energy use estimated shown in Table 2 of the AEO 2010). This natural gas source energy conversion factor was calculated by dividing the natural gas subtotal of 23.15 quads (sum of all natural gas usage, including usage for natural gas field production, leases, plant fuel, and pipeline [compression] supply) by the delivered natural gas total of 21.23 quads (sum of four primary energy sectors (residential, commercial, industrial, and transportation).

To estimate the reduction in energy cost index, DOE relied on national average commercial building energy prices of $\$ 0.1027 / \mathrm{kWh}$ of electricity and $\$ 10.06$ per $1000 \mathrm{ft}^{3}$ ( $\$ 0.9796 /$ therm) of natural gas, based on EIA statistics for 2010 (the last complete year of data available in Table 5.3, Average Retail Price of Electricity to Ultimate Consumers: Total by End-Use Sector for the commercial sector, available from EIA at http://www.eia.doe.gov/cneaf/electricity/epm/table5_3.html and for 2009 (the last complete year of data available from the EIA Natural Gas Annual Summary for the commercial sector, available at http://tonto.eia.doe.gov/dnav/ng/ng_pri_sum_dcu_nus_a.htm.) DOE recognizes that actual fuel costs will vary somewhat by building type within a region, and will in fact vary more across regions. Nevertheless, DOE believes that the use of simple national average figures illustrates whether there will be energy cost savings sufficient for the purposes of the DOE determination. 
The resulting EUI statistics by fuel type and site or primary energy are listed in Table 5 and Table 6 for Standard 90.1-2007 and Standard 90.1-2010, respectively, using ASHRAE Standard 62.1-2004 ventilation assumptions for both sets of buildings. In terms of energy expenditures per square foot per year, ECI statistics are provided as well in these tables. Table 7 presents the estimated percent energy savings (based on change in EUIs) between the 2007 and 2010 editions. Considering those differences that can be reasonably quantified, the 2010 edition will increase the energy efficiency of commercial buildings. The values listed in Table 7 represent percent energy savings.

Table 7. Estimated Percent Energy Savings with 2010 Edition - by Building Type

\begin{tabular}{|c|c|c|c|c|c|}
\hline \multirow[b]{2}{*}{ Building Type } & \multirow[b]{2}{*}{ Building Prototype } & \multirow{2}{*}{$\begin{array}{c}\text { Building Type } \\
\text { Floor Area } \\
\text { Weight } \\
\%\end{array}$} & \multicolumn{3}{|c|}{$\begin{array}{l}\text { Percent Savings in Whole Building } \\
\text { Energy Use Intensity (\%) }\end{array}$} \\
\hline & & & Site EUI & Source EUI & ECI \\
\hline \multirow[t]{3}{*}{ Office } & Small Office & 5.61 & 16.1 & 16.4 & 16.4 \\
\hline & Medium Office & 6.05 & 22.1 & 24.4 & 24.4 \\
\hline & Large Office & 3.33 & 22.3 & 21.5 & 21.5 \\
\hline \multirow[t]{2}{*}{ Retail } & Stand-Alone Retail & 15.25 & 26.1 & 24.7 & 24.7 \\
\hline & Strip Mall & 5.67 & 16.8 & 18.9 & 18.9 \\
\hline \multirow[t]{2}{*}{ Education } & Primary School & 4.99 & 24.2 & 20.8 & 20.8 \\
\hline & Secondary School & 10.36 & 26.7 & 23.3 & 23.2 \\
\hline \multirow[t]{2}{*}{ Healthcare } & Outpatient Health Care & 4.37 & 22.6 & 22.2 & 22.2 \\
\hline & Hospital & 3.45 & 24.5 & 20.1 & 20.1 \\
\hline \multirow[t]{2}{*}{ Lodging } & Small Hotel & 1.72 & 5.9 & 7.7 & 7.7 \\
\hline & Large Hotel & 4.95 & 11.0 & 10.5 & 10.5 \\
\hline Warehouse & Non-Refrigerated Warehouse & 16.72 & 20.7 & 23.1 & 23.1 \\
\hline \multirow[t]{2}{*}{ Food Service } & Fast Food Restaurant & 0.59 & 5.1 & 8.6 & 8.6 \\
\hline & Sit-Down Restaurant & 0.66 & 13.5 & 19.3 & 19.4 \\
\hline \multirow[t]{2}{*}{ Apartment } & Mid-Rise Apartment & 7.32 & 6.8 & 4.4 & 4.4 \\
\hline & High-Rise Apartment & 8.97 & 7.2 & 4.5 & 4.5 \\
\hline National & & 100 & 18.5 & 18.2 & 18.2 \\
\hline
\end{tabular}




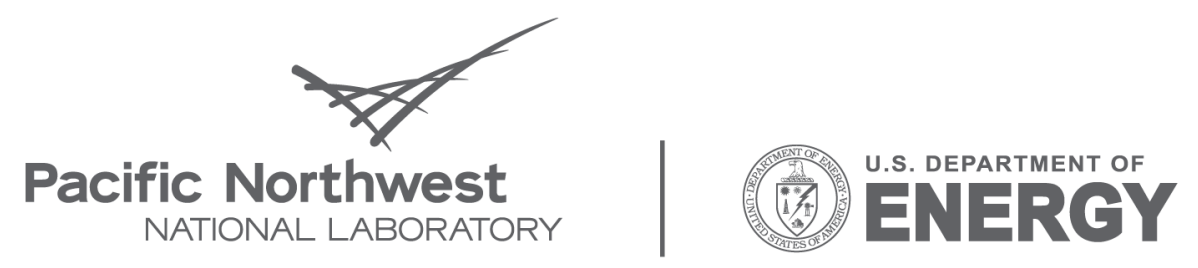

Proudly Operated by Battelle Since 1965

902 Battelle Boulevard

P.O. Box 999

Richland, WA 99352

1-888-375-PNNL (7665)

www.pnl.gov 